\title{
AN ASSESSMENT APPROACH FOR NON-GOVERNMENTAL ORGANIZATIONS IN HUMANITARIAN RELIEF LOGISTICS AND AN APPLICATION IN TURKEY
}

\author{
Erkan CELIK, Alev TASKIN GUMUS \\ Department of Industrial Engineering, Yildiz Technical University, 34349 Besiktas-Istanbul, Turkey
}

Received 8 February 2014; accepted 31 January 2015

\begin{abstract}
The ever-increasing natural disasters have been causing the loss of lives, properties and resources. By the preparedness and response ability of non-governmental organizations, it is aimed to minimize these losses. In this paper, first, the critical success factors of humanitarian relief logistics management operations are determined and categorized. Then, by considering these factors, a hybrid method that consists of trapezoidal interval type-2 fuzzy sets, AHP and TOPSIS, is proposed to evaluate emergency preparedness and response ability performance of non-governmental relief organizations. The proposed hybrid method is applied for non-governmental relief organizations in Turkey to evaluate their performance, and to the factors need to be improved for each determined organization.
\end{abstract}

Keywords: non-governmental relief organizations, emergency management, multiple criteria analysis, trapezoidal interval type-2 fuzzy sets, AHP, TOPSIS.

JEL Classification: D81, L3.

\section{Introduction}

According to the records of the Centre for Research on the Epidemiology of Disasters (EM-DAT), 5,714 natural disasters have been registered between 2000 and 2013. The EM-DAT estimates 1,554.9 billions of dollars in economic damage from these events, $1,195,520$ casualties, and 2,898 millions of affected people. It has been estimated that ten disasters, including Van (Ercis) earthquake in Turkey, that took place between 2004 and 2013, resulted in 867 casualties and USD 2,611 million in economic damages, which affected 236,522 people (EM-DAT 2013). These statistics show the need to develop strategies in order to reduce the impact of disasters for humankind. Activities of humanitarian relief logistics management (HRLM) directly focus on helping the sufferers and injured people

Corresponding author Alev Taskin Gumus

E-mail: ataskin@yildiz.edu.tr 
on disaster areas. In other words, its first aim is saving the lives of people and decreasing the death rate during and after a disaster.

Each of the international humanitarian relief organizations, governments, local and regional relief organizations, and private sector companies may have different interests, mandates, capacity, and logistics expertise (Balcik et al. 2010). All humanitarian relief actors must improve their performance to respond effectively to a disaster because there is a lack of resources (Bui et al. 2000). During the Asian Tsunami of 2004, more than 40 countries and 700 non-governmental organizations (NGOs) provided subsequent humanitarian assistance (Chia 2007; Balcik et al. 2010). Hence, improving preparedness and response ability to humanitarian relief among NGOs is crucial. The NGO supply chains generally deal with disasters, and the majority of the literature deals only with analytical models (Natarajarathinam et al. 2009).

This paper evaluates NGOs for the successful operation of HRLM activities with respect to critical success factors (CSFs) of emergency management. Therefore, a hybrid method that consists of trapezoidal interval type-2 fuzzy sets, AHP and TOPSIS is proposed to evaluate emergency preparedness and response ability performances of non-governmental relief organizations. Trapezoidal interval type- 2 fuzzy sets are used here because of involving more uncertainties than type-1 fuzzy sets. It is provided additional degrees of freedom to represent the uncertainty and the fuzziness of the real world (Chen, Lee 2010). To address this concern, first, an effective method that combines type- 2 fuzzy sets and analytic hierarchy process (AHP) is proposed to determine the importance weights of CSFs determined for HRLM operations. And then, by benefiting these weights, trapezoidal interval type-2 fuzzy TOPSIS is used to evaluate the NGOs' preparedness and response abilities. It is aimed that the results will be beneficial for our country and NGOs to evaluate their humanitarian relief operation performance.

The rest of this paper is organized as follows: Section 1 briefly reviews the literature to determine and categorize the CSFs of HRLM operations. Section 2 presents the trapezoidal interval type- 2 fuzzy sets, trapezoidal interval type-2 fuzzy AHP and trapezoidal interval type-2 fuzzy TOPSIS approaches, used in the proposed method to evaluate the NGOs. Then, the application of the proposed method to evaluate the CSFs and NGOs for Turkey is presented and, a sensitivity analysis is conducted in Section 3. Finally, the conclusion is given in last section.

\section{The critical success factors of HRLM operations}

The concept of success factors was first developed by Daniel (1961). It is extensively applied to various contexts such as organizational management, operational management, supply chain management, enterprise resource management and so on (Freund 1988; Holland, Light 1999; Sumner 1999; Power et al. 2001). Gunasekaran and Ngai (2003) describe five key functions critical to a small logistics company as: strategic planning, inventory management, transportation planning, capacity planning, and information management. Seneviratne et al. (2010) identify a list of success factors to be considered in disaster knowledge management based on literature survey and review. These success factors are classified into 
several categories as: technological, social, legal, environmental, economic, functional, institutional and political based on their characteristics. These factors are general for all types of disasters and considered the three phases; mitigation/preparedness, relief/recovery and reconstruction/rehabilitation, by covering many affected countries. Moe and Pathranarakul (2006) specify critical success factors for managing disaster related public projects. Moe et al. (2007) propose a balanced scorecard for maximizing desired outcomes from natural disaster projects. Zhou et al. (2011) point out the most existing studies for emergency management trying to optimize certain procedures. As a contribution to the supply chain management literature for HRLM, this paper investigates to identify the CSFs and their ranking for the successful HRLM operations. Lu et al. (2006) discuss CSFs for emergency relief logistics and focus on Taiwanese agencies' response to crises. They consider six independent criteria groups as strategic planning, inventory management, transport and capacity planning, information and human resource management, continuous improvement and collaboration, and technology utilization. Pettit and Beresford (2009) apply CSFs to humanitarian aid sector based on commercial context. They also present the importance of understanding that which factors are critical to the success of HRLM. Zhou et al. (2011) identify five CSFs for emergency management using fuzzy DEMATEL. They also emphasize the great importance and impact of CSFs on the emergency response. CSFs are indispensable for a successful relief activity, and directly contribute to obtain the success. According to their result, reasonable organizational structure and clear awareness of responsibilities are determined to have highest impact on the whole system. Celik et al. (2013a) identify and evaluate the critical success factors of HRLM. Abidi et al. (2013) classify the key success factors of humanitarian supply chain in strategic, tactical and operational level. Abidi et al. (2014) present a systematic literature review for humanitarian supply chain performance management. They used 94 humanitarian supply chain performance indicators.

In this study, the CSFs for HRLM are determined and classified through literature review and expert interviews. The predetermined CFSs based on literature review are asked to experts for determining final hierarchical structure for HRLM. The aim of the interviews is seeking to analyze which of the predetermined CSFs are crucial for effective and efficient preparedness and response for HRLM. According to some experts, who work as logisticians, suitability of roof and rack systems and suitability of heating-cooling systems are two important CSFs for warehousing. These two CSFs are taken into consideration after interviews but the other CSFs are predetermined and these CSFs are also confirmed by experts. As the result of the experts' interviews, five different main criteria are categorized and determined as; management and planning, organization, transportation and distribution, warehousing, and information systems. Management and planning covers a wide and complex body of knowledge for evaluating preparedness and response of a disaster. It is also clear that effective management and planning incorporate NGOs' policies which need to be more adequately defined. A well designed organizational structure plays a major role in order to be prepared and to response effectively to a disaster. Transportation and distribution is an important problem encountered by NGOs. Transportation and distribution is also the second largest overhead cost of humanitarian organizations (Disparte 2007; Van Wassenhove, Pedraza Martinez 2012). The NGOs are obliged to preposition and store 
their items and equipment in the most suitable warehouse considering possible disaster areas. Most of the studies in literature present optimization models for warehouse location selection (Yushimito et al. 2012; Jia et al. 2007; Döyen et al. 2012; Balcik, Beamon 2008; Rawls, Turnquist 2010; Duran et al. 2011; Gunnec, Salman 2007). Information systems are critical to the success or failure of humanitarian logistics (Marx 2009). It can only respond successfully to the affected area through an efficient information systems infrastructure. Hence, NGOs must improve their information system. Leiras et al. (2014) present a literature review for humanitarian logistics that aims to identify trends and challenges. They conclude that technologies and management models used in logistics business can also be seized for performance improvements in humanitarian operations.

The surveys with the expert interviewees are conducted to clarify the criteria and subcriteria as supporting the literature review, and collect evaluation data for each main criteria and sub-criteria, representing CSFs. Each of the determined five main criteria can be thought as one for each dimension of process. It is possible to say that activities of humanitarian relief logistics include mainly five different criteria, and all these dimensions must be satisfied in order to be successful. After determining the main factors, the sub-criteria which are important to satisfy each main factor are determined. Finally, all the criteria and their brief literature review can be seen in Table 1. One of the contributions of our paper for the field is to determine and categorize these CSFs for HRLM field.

\section{The integrated MCDM approach based on trapezoidal interval type-2 fuzzy sets}

AHP and TOPSIS approaches are integrated by researchers for different applications as; a suitable partner selection for a strategic alliance in a logistics value chain (Buyukozkan et al. 2008), facility location selection (Ertugrul, Karakasoglu 2008), supplier selection (Jolai et al. 2011; Wang et al. 2009; Zeydan et al. 2011), selecting a cleaning system for pieces of four stroke engines, (Garcia-Cascales, Lamata 2009), material selection (Rathod, Kanzaria 2011), prioritizing effective 7Ms: Management, Manpower, Marketing, Method, Machine, Material, and Money (Rostamzadeh, Sofian 2011), evaluating notebook computer companies (Sun 2010), evaluating airline service quality (Tsaur et al. 2002), hazardous waste transportation firm selection (Gumus 2009), solid waste transhipment site selection problem (Onut, Soner 2008), extinguisher ozone depleting substance (Aiello et al. 2009), refractured well selection (Li et al. 2012), government investments in higher education (Kahraman et al. 2013). The literature on multi criteria decision making (MCDM) is too large to present here. Two comprehensive review papers on MCDM and fuzzy MCDM literature have been recently presented by Zavadskas et al. (2014) and Mardani et al. (2015). Interested readers are directed to read these useful review papers.

Here, first, we integrate trapezoidal interval type-2 AHP and trapezoidal interval type-2 TOPSIS to evaluate the NGOs' preparedness and response abilities. In this section, the basic definitions of trapezoidal type-2 fuzzy sets (Mendel et al. 2006; Lee, Chen 2008; Chen, Lee 2010; Celik et al. 2013b), the procedure of AHP (Buckley 1985; Gumus 2009; Gumus et al. 2013) and TOPSIS (Hwang, Yoon 1981; Chen 2000; Chen, Lee 2010; Nasab, Rostamy-Malkhalifeh 2010; Celik et al. 2012) based on trapezoidal interval type-2 fuzzy sets are briefly introduced mathematically. 
Table 1. Summary of literature review for main and sub-criteria

\begin{tabular}{|c|c|c|}
\hline Criteria & Sub-criteria & Sources \\
\hline \multirow{5}{*}{ 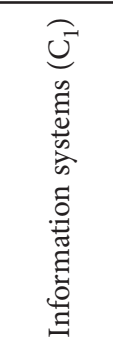 } & Early Warning Systems $\left(\mathrm{C}_{11}\right)$ & $\begin{array}{l}\text { Ju et al. 2012; Oloruntoba 2010; Seneviratne } \\
\text { et al. } 2010\end{array}$ \\
\hline & Short Answer and Feedback Time $\left(\mathrm{C}_{12}\right)$ & Zhou et al. 2011; Oloruntoba 2010 \\
\hline & $\begin{array}{l}\text { Effective Communication and } \\
\text { Emergency Information Systems }\left(\mathrm{C}_{13}\right)\end{array}$ & $\begin{array}{l}\text { Zhou et al. 2011; Ju et al. 2012; Apte 2009; } \\
\text { Moe, Pathranarakul 2006; Moe et al. } 2007\end{array}$ \\
\hline & Quick and Effective Reporting $\left(\mathrm{C}_{14}\right)$ & $\begin{array}{l}\text { Pettit, Beresford 2005; Zhou et al. 2011; Moe, } \\
\text { Pathranarakul } 2006\end{array}$ \\
\hline & Effective Information Analysis $\left(\mathrm{C}_{15}\right)$ & $\begin{array}{l}\text { Zhou et al. 2011; Apte 2009; Moe, } \\
\text { Pathranarakul 2006 }\end{array}$ \\
\hline \multirow{5}{*}{ 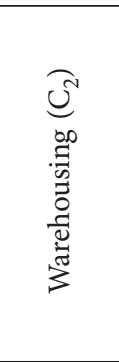 } & Suitability of Warehouse Location $\left(\mathrm{C}_{21}\right)$ & $\begin{array}{l}\text { Lu et al. 2006; Beamon, Balcik 2008; Apte } \\
2009\end{array}$ \\
\hline & $\begin{array}{l}\text { Suitability of Roof and Rack Systems } \\
\left(\mathrm{C}_{22}\right)\end{array}$ & \\
\hline & Suitability of Warehouse Personnel $\left(\mathrm{C}_{23}\right)$ & Zhou et al. 2011 \\
\hline & $\begin{array}{l}\text { Suitability of Warehouse Tools } \\
\text { and Vehicles }\left(C_{24}\right)\end{array}$ & Lu et al. 2006; Pettit, Beresford 2009 \\
\hline & $\begin{array}{l}\text { Suitability of Heating-Cooling Systems } \\
\left(\mathrm{C}_{25}\right)\end{array}$ & \\
\hline \multirow{5}{*}{ 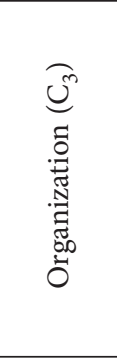 } & Organizational Structure $\left(\mathrm{C}_{31}\right)$ & $\begin{array}{l}\text { Oloruntoba 2005; Davidson 2006; Zhou et al. } \\
2011\end{array}$ \\
\hline & Employee Training $\left(\mathrm{C}_{32}\right)$ & Oloruntoba 2010; Zhou et al. 2011; Apte 2009 \\
\hline & $\begin{array}{l}\text { Continuous Improvement } \\
\text { and Corporation }\left(\mathrm{C}_{33}\right)\end{array}$ & $\begin{array}{l}\text { Kovacs, Spens 2007; Pettit, Beresford 2009; } \\
\text { Zhou et al. } 2011\end{array}$ \\
\hline & Performance Evaluation System $\left(\mathrm{C}_{34}\right)$ & $\begin{array}{l}\text { Pettit, Beresford 2009; Balcik, Beamon 2008; } \\
\text { Sandwell } 2011\end{array}$ \\
\hline & Certain Job Descriptions $\left(\mathrm{C}_{35}\right)$ & $\begin{array}{l}\text { Oloruntoba 2005; Davidson 2006; Zhou et al. } \\
\text { 2011; Sandwell 2011; Moe, Pathranarakul } 2006\end{array}$ \\
\hline \multirow{5}{*}{ 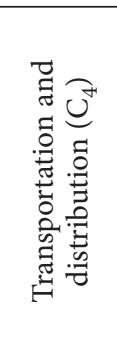 } & Safety of Personnel and Inventory $\left(\mathrm{C}_{41}\right)$ & Beamon, Balcik 2008; Zhou et al. 2011 \\
\hline & Distribution Speed $\left(\mathrm{C}_{42}\right)$ & $\begin{array}{l}\text { Beamon, Balcik 2008; Petit, Bresford 2009; } \\
\text { Zhou et al. 2011; Apte 2009; Moe et al. } 2007\end{array}$ \\
\hline & $\begin{array}{l}\text { Suitability of Distribution Personnel } \\
\left(\mathrm{C}_{43}\right)\end{array}$ & Pettit, Beresford 2009 \\
\hline & Suitability of Distribution Vehicles $\left(\mathrm{C}_{44}\right)$ & $\begin{array}{l}\text { Petit, Bresford 2009; Van Wassenhove, } \\
\text { Martinez } 2012\end{array}$ \\
\hline & Suitability of Distribution Network $\left(\mathrm{C}_{45}\right)$ & $\begin{array}{l}\text { Pettit, Beresford 2005, 2009; Sandwell 2011; } \\
\text { Seneviratne et al. } 2010\end{array}$ \\
\hline \multirow{5}{*}{ 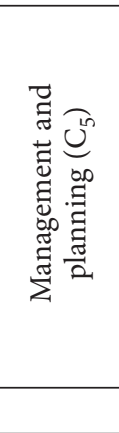 } & $\begin{array}{l}\text { Strategic and Operational Planning } \\
\left(\mathrm{C}_{51}\right)\end{array}$ & $\begin{array}{l}\text { Fritz Institute 2005; Lu et al. 2006; Pettit, } \\
\text { Beresford 2009; Moe, Pathranarakul } 2006\end{array}$ \\
\hline & $\begin{array}{l}\text { Effective Human Resource Management } \\
\text { System }\left(\mathrm{C}_{52}\right)\end{array}$ & $\begin{array}{l}\text { Pettit, Beresford 2009; Apte 2009; Tomasini, } \\
\text { Van Wassenhove 2009; Moe, Pathranarakul } \\
2006\end{array}$ \\
\hline & Effective Inventory Management $\left(\mathrm{C}_{53}\right)$ & $\begin{array}{l}\text { Beamon, Kotleba 2006; Whybark 2007; Petit, } \\
\text { Bresford } 2009\end{array}$ \\
\hline & Well-Planned Supply System $\left(\mathrm{C}_{54}\right)$ & $\begin{array}{l}\text { Davidson 2006; Pettit, Beresford 2009; Zhou } \\
\text { et al. 2011; Oloruntoba 2010; Seneviratne } \\
\text { et al. 2010; Moe, Pathranarakul } 2006\end{array}$ \\
\hline & Effective Suppliers Relationships $\left(\mathrm{C}_{55}\right)$ & Beamon, Balcik 2008 \\
\hline
\end{tabular}




\subsection{Trapezoidal interval type-2 fuzzy sets}

In this section, some definitions about trapezoidal type-2 fuzzy sets and trapezoidal interval type-2 fuzzy sets are briefly reviewed mathematically (Mendel et al. 2006; Lee, Chen 2008; Chen, Lee 2010; Celik et al. 2013b).

Definition 1. A type-2 fuzzy set $\tilde{\tilde{A}}$ in the universe of discourse $X$ can be represented by a type-2 membership function $\mu_{\tilde{\tilde{A}}}$, shown as follows:

$$
\tilde{\tilde{A}}=\left\{\left((x, u), \mu_{\tilde{\tilde{A}}}(x, u)\right) \mid \forall x \in X, \forall u \in J_{X} \subseteq[0,1], 0 \leq \mu_{\tilde{\tilde{A}}}(x, u) \leq 1\right\},
$$

where $J_{X}$ denotes an interval in $(0,1)$. Moreover, the type-2 fuzzy set $\tilde{\tilde{A}}$ also can be represented as follows:

$$
\tilde{\tilde{A}}=\int_{x \in X} \int_{u \in J_{X}} \mu_{\tilde{\tilde{A}}}(x, u) /(x, u),
$$

where $J_{X} \subseteq[0,1]$ and $\iint$ denotes union over all admissible $x$ and $u$.

Definition 2. Let $\tilde{\tilde{A}}$ be a type-2 fuzzy set in the universe of discourse X represented by the type-2 membership function $\mu_{\tilde{\tilde{A}}}$. If all $\underset{\tilde{\tilde{A}}}{\tilde{A}}(x, u)=1$, then $\tilde{\tilde{A}}$ is called as an interval type-2 fuzzy set. An interval type-2 fuzzy set $\tilde{A}$ can be regarded as a special case of a type- 2 fuzzy set, represented as follows:

$$
\tilde{\tilde{A}}=\int_{x \in X} \int_{u \in J_{X}} 1 /(x, u) \text { where } J_{X} \subseteq[0,1] .
$$

Definition 3. The upper and the lower membership function of an interval type2 fuzzy set are type-1 membership functions, respectively. In this paper, we present a method using interval type-2 fuzzy sets for handling fuzzy multiple attributes group decision-making problems, where the reference points and the heights of the upper and the lower membership functions of interval type- 2 fuzzy sets are used to characterize interval type-2 fuzzy sets. Figure 1 shows a trapezoidal interval type- 2 fuzzy set $\tilde{\tilde{A}}_{i}=\left(\tilde{A}_{i}^{U}, \tilde{A}_{i}^{L}\right)=\left(\left(a_{i 1}^{U}, a_{i 2}^{U}, a_{i 3}^{U}, a_{i 4}^{U} ; H_{1}\left(\tilde{A}_{i}^{U}\right), H_{2}\left(\tilde{A}_{i}^{U}\right)\right),\left(a_{i 1}^{L}, a_{i 2}^{L}, a_{i 3}^{L}, a_{i 4}^{L} ; H_{1}\left(\tilde{A}_{i}^{L}\right), H_{2}\left(\tilde{A}_{i}^{L}\right)\right)\right)$, where $\tilde{A}_{i}^{U}$ and $\tilde{A}_{i}^{L}$ are type-1 fuzzy sets, $a_{i 1}^{U}, a_{i 2}^{U}, a_{i 3}^{U}, a_{i 4}^{U}, a_{i 1}^{L}, a_{i 2}^{L}, a_{i 3}^{L}$ and $a_{i 4}^{L}$ are the reference points of the interval type-2 fuzzy $\tilde{\tilde{A}}_{i} ; H_{j}\left(\tilde{A}_{i}^{U}\right)$ denotes the membership value of

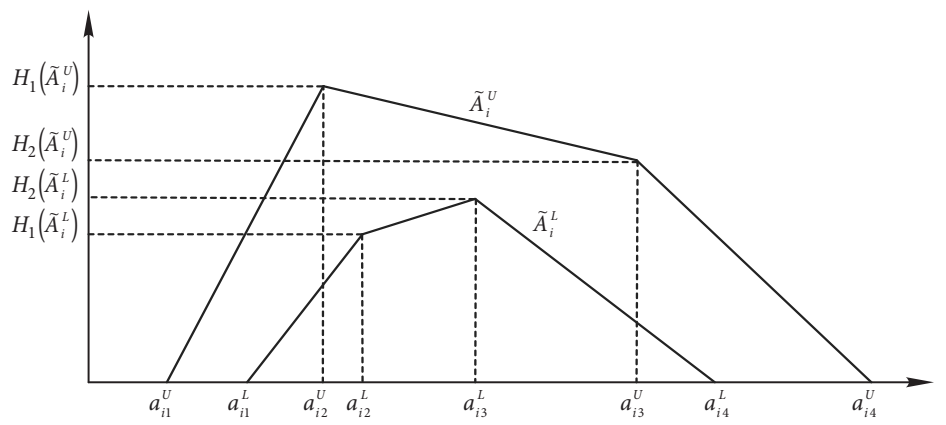

Fig. 1. The trapezoidal interval type-2 fuzzy sets membership function 
the element $a_{i(j+1)}^{U}$ in the upper trapezoidal membership function $\tilde{A}_{i}^{U} ; 1 \leq j \leq 2, H_{j}\left(\tilde{A}_{i}^{L}\right)$ denotes the membership value of the element $a_{i(j+1)}^{L}$ in the lower trapezoidal membership function $\tilde{A}_{i}^{L} ; 1 \leq j \leq 2, H_{j}\left(\tilde{A}_{i}^{L}\right)$;

$$
H_{1}\left(\tilde{A}_{i}^{U}\right) \in[0,1], H_{2}\left(\tilde{A}_{i}^{U}\right) \in[0,1], H_{1}\left(\tilde{A}_{i}^{L}\right) \in[0,1], H_{2}\left(\tilde{A}_{i}^{L}\right) \in[0,1] \text { and } 1 \leq i \leq n .
$$

Definition 4. The addition operation between the trapezoidal interval type-2 fuzzy sets:

$$
\begin{aligned}
& \tilde{\tilde{A}}_{1}=\left(\tilde{A}_{1}^{U}, \tilde{A}_{1}^{L}\right)=\left(\left(a_{11}^{U}, a_{12}^{U}, a_{13}^{U}, a_{14}^{U} ; H_{1}\left(\tilde{A}_{1}^{U}\right), H_{2}\left(\tilde{A}_{1}^{U}\right)\right),\left(a_{11}^{L}, a_{12}^{L}, a_{13}^{L}, a_{14}^{L} ; H_{1}\left(\tilde{A}_{1}^{L}\right), H_{2}\left(\tilde{A}_{1}^{L}\right)\right)\right) ; \\
& \tilde{\tilde{A}}_{2}=\left(\tilde{A}_{2}^{U}, \tilde{A}_{2}^{L}\right)=\left(\left(a_{21}^{U}, a_{22}^{U}, a_{23}^{U}, a_{24}^{U} ; H_{1}\left(\tilde{A}_{2}^{U}\right), H_{2}\left(\tilde{A}_{2}^{U}\right)\right),\left(a_{21}^{L}, a_{22}^{L}, a_{23}^{L}, a_{24}^{L} ; H_{1}\left(\tilde{A}_{2}^{L}\right), H_{2}\left(\tilde{A}_{2}^{L}\right)\right)\right) \text {; } \\
& \tilde{A}_{1} \oplus \tilde{A}_{2}=\left(\tilde{A}_{1}^{U}, \tilde{A}_{1}^{L}\right) \oplus\left(\tilde{A}_{2}^{U}, \tilde{A}_{2}^{L}\right)= \\
& \left(\begin{array}{l}
\left(a_{11}^{U}+a_{21}^{U}, a_{12}^{U}+a_{22}^{U}, a_{13}^{U}+a_{23}^{U}, a_{14}^{U}+a_{24}^{U} ; \min \left(H_{1}\left(\tilde{A}_{1}^{U}\right), H_{1}\left(\tilde{A}_{2}^{U}\right)\right), \min \left(H_{2}\left(\tilde{A}_{1}^{U}\right), H_{2}\left(\tilde{A}_{2}^{U}\right)\right)\right), \\
\left(a_{11}^{L}+a_{21}^{L}, a_{12}^{L}+a_{22}^{L}, a_{13}^{L}+a_{23}^{L}, a_{14}^{L}+a_{24}^{L} ; \min \left(H_{1}\left(\tilde{A}_{1}^{L}\right), H_{1}\left(\tilde{A}_{2}^{L}\right)\right), \min \left(H_{2}\left(\tilde{A}_{1}^{L}\right), H_{2}\left(\tilde{A}_{2}^{L}\right)\right)\right)
\end{array}\right) .
\end{aligned}
$$

Definition 5. The subtraction operation between the trapezoidal interval type- 2 fuzzy sets

$$
\begin{aligned}
& \tilde{A}_{1} \Theta \tilde{A}_{2}=\left(\tilde{A}_{1}^{U}, \tilde{A}_{1}^{L}\right) \Theta\left(\tilde{A}_{2}^{U}, \tilde{A}_{2}^{L}\right)= \\
& \left(\begin{array}{l}
\left(a_{11}^{U}-a_{21}^{U}, a_{12}^{U}-a_{22}^{U}, a_{13}^{U}-a_{23}^{U}, a_{14}^{U}-a_{24}^{U} ; \min \left(H_{1}\left(\tilde{A}_{1}^{U}\right), H_{1}\left(\tilde{A}_{2}^{U}\right)\right), \min \left(H_{2}\left(\tilde{A}_{1}^{U}\right), H_{2}\left(\tilde{A}_{2}^{U}\right)\right)\right), \\
\left(a_{11}^{L}-a_{21}^{L}, a_{12}^{L}-a_{22}^{L}, a_{13}^{L}-a_{23}^{L}, a_{14}^{L}-a_{24}^{L} ; \min \left(H_{1}\left(\tilde{A}_{1}^{L}\right), H_{1}\left(\tilde{A}_{2}^{L}\right)\right), \min \left(H_{2}\left(\tilde{A}_{1}^{L}\right), H_{2}\left(\tilde{A}_{2}^{L}\right)\right)\right)
\end{array}\right) .
\end{aligned}
$$

Definition 6. The multiplication operation between the trapezoidal interval type- 2 fuzzy sets:

$$
\begin{aligned}
& \tilde{A}_{1} \otimes \tilde{A}_{2}=\left(\tilde{A}_{1}^{U}, \tilde{A}_{1}^{L}\right) \otimes\left(\tilde{A}_{2}^{U}, \tilde{A}_{2}^{L}\right)= \\
& \left(\begin{array}{l}
\left(a_{11}^{U} \times a_{21}^{U}, a_{12}^{U} \times a_{22}^{U}, a_{13}^{U} \times a_{23}^{U}, a_{14}^{U} \times a_{24}^{U} ; \min \left(H_{1}\left(\tilde{A}_{1}^{U}\right), H_{1}\left(\tilde{A}_{2}^{U}\right)\right), \min \left(H_{2}\left(\tilde{A}_{1}^{U}\right), H_{2}\left(\tilde{A}_{2}^{U}\right)\right)\right), \\
\left(a_{11}^{L} \times a_{21}^{L}, a_{12}^{L} \times a_{22}^{L}, a_{13}^{L} \times a_{23}^{L}, a_{14}^{L} \times a_{24}^{L} ; \min \left(H_{1}\left(\tilde{A}_{1}^{L}\right), H_{1}\left(\tilde{A}_{2}^{L}\right)\right), \min \left(H_{2}\left(\tilde{A}_{1}^{L}\right), H_{2}\left(\tilde{A}_{2}^{L}\right)\right)\right)
\end{array}\right) .
\end{aligned}
$$

Definition 7. The arithmetic operations between the trapezoidal interval type-2 fuzzy sets:

$$
\begin{aligned}
& k \tilde{\tilde{A}}_{1}=\left(\begin{array}{l}
\left(k \times a_{11}^{U}, k \times a_{12}^{U}, k \times a_{13}^{U}, k \times a_{14}^{U} ; H_{1}\left(\tilde{A}_{1}^{U}\right), H_{2}\left(\tilde{A}_{1}^{U}\right)\right), \\
\left(k \times a_{11}^{L}, k \times a_{12}^{L}, k \times a_{13}^{L}, k \times a_{14}^{L} ; H_{1}\left(\tilde{A}_{1}^{L}\right), H_{2}\left(\tilde{A}_{1}^{L}\right)\right)
\end{array}\right) ; \\
& \frac{\tilde{\tilde{A}}_{1}}{k}=\left(\begin{array}{l}
\left(\frac{1}{k} \times a_{11}^{U}, \frac{1}{k} \times a_{12}^{U}, \frac{1}{k} \times a_{13}^{U}, \frac{1}{k} \times a_{14}^{U} ; H_{1}\left(\tilde{A}_{1}^{U}\right), H_{2}\left(\tilde{A}_{1}^{U}\right)\right), \\
\left(\frac{1}{k} \times a_{11}^{L}, \frac{1}{k} \times a_{12}^{L}, \frac{1}{k} \times a_{13}^{L}, \frac{1}{k} \times a_{14}^{L} ; H_{1}\left(\tilde{A}_{1}^{L}\right), H_{2}\left(\tilde{A}_{1}^{L}\right)\right)
\end{array}\right) .
\end{aligned}
$$




\subsection{Trapezoidal interval type-2 fuzzy AHP}

Buckley's fuzzy AHP algorithm is preferred to determine criteria weights since it is easy to extend to the fuzzy case, guarantees a unique solution to the reciprocal comparison matrix and the steps of this approach are relatively easier than the other fuzzy AHP approaches (Gumus 2009; Gumus et al. 2013). The proposed trapezoidal interval type-2 fuzzy AHP (TIT2FAHP) in consideration with Buckley (1985) can be summarized as follows.

Step 1. Construct fuzzy pair wise comparison matrix among all the criteria in the hierarchical structure. Assign linguistic terms shown in Table 2, to the pair wise comparisons by asking which is more important of each two criteria, such as:

$$
\begin{gathered}
\tilde{\tilde{M}}=\left(\begin{array}{cccc}
1 & \tilde{\tilde{a}}_{12} & \cdots & \tilde{\tilde{a}}_{1 n} \\
\tilde{\tilde{a}}_{21} & 1 & \cdots & \tilde{\tilde{a}}_{2 n} \\
\vdots & \vdots & \ddots & \vdots \\
\tilde{\tilde{a}}_{n 1} & \tilde{\tilde{a}}_{n 2} & \cdots & 1
\end{array}\right)=\left(\begin{array}{cccc}
1 & \tilde{\tilde{a}}_{12} & \cdots & \tilde{\tilde{a}}_{1 n} \\
\tilde{\tilde{1}} / \tilde{\tilde{a}}_{12} & 1 & \cdots & \tilde{\tilde{a}}_{2 n} \\
\vdots & \vdots & \ddots & \vdots \\
\tilde{\tilde{1}} / \tilde{\tilde{a}}_{1 n} & \tilde{\tilde{1}}^{1} / \tilde{\tilde{a}}_{2 n} & \cdots & 1
\end{array}\right), \\
\text { where } / \tilde{\tilde{a}}_{i j}=\left(\begin{array}{l}
\left(\frac{1}{a_{i j 4}^{U}}, \frac{1}{a_{i j 3}^{U}}, \frac{1}{a_{i j 2}^{U}}, \frac{1}{a_{i j 1}^{U}} ; H_{1}\left(a_{i j}^{U}\right), H_{2}\left(a_{i j}^{U}\right)\right), \\
\left(\frac{1}{a_{i j 4}^{L}}, \frac{1}{a_{i j 3}^{L}}, \frac{1}{a_{i j 2}^{L}}, \frac{1}{a_{i j 1}^{L}} ; H_{1}\left(a_{i j}^{L}\right), H_{2}\left(a_{i j}^{L}\right)\right)
\end{array}\right) .
\end{gathered}
$$

\begin{tabular}{|c|c|c|c|}
\hline $\begin{array}{l}\text { Linguistic } \\
\text { variable }\end{array}$ & $\begin{array}{l}\text { Crisp } \\
\text { number }\end{array}$ & $\begin{array}{l}\text { Type-1 fuzzy } \\
\text { number }\end{array}$ & Type-2 fuzzy number \\
\hline $\begin{array}{l}\text { Absolutely } \\
\text { strong (AS) }\end{array}$ & 9 & $(8 ; 9 ; 9 ; 10)$ & $((8 ; 9 ; 9 ; 10 ; 1 ; 1),(8.5 ; 9 ; 9 ; 9.5 ; 0.9 ; 0.9))$ \\
\hline $\begin{array}{l}\text { Very strong } \\
\text { (VS) }\end{array}$ & 7 & $(6 ; 7 ; 7 ; 8)$ & $((6 ; 7 ; 7 ; 8 ; 1 ; 1),(6.5 ; 7 ; 7 ; 7.5 ; 0.9 ; 0.9))$ \\
\hline $\begin{array}{l}\text { Fairly strong } \\
\text { (FS) }\end{array}$ & 5 & $(4 ; 5 ; 5 ; 6)$ & $((4 ; 5 ; 5 ; 6 ; 1 ; 1),(4.5 ; 5 ; 5 ; 5.5 ; 0.9 ; 0.9))$ \\
\hline $\begin{array}{l}\text { Slightly } \\
\text { strong (SS) }\end{array}$ & 3 & $(2 ; 3 ; 3 ; 4)$ & $((2 ; 3 ; 3 ; 4 ; 1 ; 1),(2.5 ; 3 ; 3 ; 4.5 ; 0.9 ; 0.9))$ \\
\hline Equal (E) & 1 & $(1 ; 1 ; 1 ; 1)$ & $((1 ; 1 ; 1 ; 1 ; 1 ; 1),(1 ; 1 ; 1 ; 1 ; 0.9 ; 0.9))$ \\
\hline $\begin{array}{l}\text { Slightly weak } \\
\text { (SW) }\end{array}$ & $1 / 3$ & $(0.25 ; 0.33 ; 0.33 ; 0.5)$ & $((0.25 ; 0.33 ; 0.33 ; 0.5 ; 1 ; 1),(0.22 ; 0.33 ; 0.33 ; 0.4 ; 0.9 ; 0.9))$ \\
\hline $\begin{array}{l}\text { Fairly weak } \\
\text { (FW) }\end{array}$ & $1 / 5$ & $(0.17 ; 0.2 ; 0.2 ; 0.25)$ & $((0.17 ; 0.2 ; 0.2 ; 0.25 ; 1 ; 1),(0.18 ; 0.2 ; 0.2 ; 0.22 ; 0.9 ; 0.9))$ \\
\hline $\begin{array}{l}\text { Very weak } \\
\text { (VW) }\end{array}$ & $1 / 7$ & $(0.13 ; 0.14 ; 0.14 ; 0.17)$ & $((0.13 ; 0.14 ; 0.14 ; 0.17 ; 1 ; 1),(0.13 ; 0.14 ; 0.14 ; 0.15 ; 0.9 ; 0.9))$ \\
\hline $\begin{array}{l}\text { Absolutely } \\
\text { weak (AW) }\end{array}$ & $1 / 9$ & $(0.1 ; 0.11 ; 0.11 ; 0.13)$ & $((0.1 ; 0.11 ; 0.11 ; 0.13 ; 1 ; 1),(0.11 ; 0.11 ; 0.11 ; 0.12 ; 0.9 ; 0.9))$ \\
\hline
\end{tabular}

Table 2. Fuzzy evaluation scale for the weights 
Step 2. Examine the consistency of the fuzzy pair wise comparison. In this step, if the result of the $A$ is consistent, then the result of the $\tilde{\tilde{A}}$ is also consistent. In order to identify the consistency ratio (CR) of a matrix, first the matrix consistency index $\mathrm{CI}$ is found as follows:

where $A w=\lambda_{\max } w$.

$$
C I=\left(\lambda_{\max }-n\right) /(n-1),
$$

Then, the consistency index of a randomly generated reciprocal matrix with reciprocal forces is called the random index (RI) that depends on $(n)$ and is calculated using the matrix order $(n)$ and the table explained by Saaty (1980). $\lambda_{\max }$ is the largest or principal eigen value of the $A$ decision matrix of pairwise comparison. It turns out that $A$ is consistent if and only if $\lambda_{\max }=n$ and that we always have $\lambda_{\max } \geq n$. A CR of 0.1 or less is considered acceptable. So, the matrix consistency ratio is calculated using:

$$
C R=C I / R I \text {. }
$$

Step 3. Use geometric mean technique to define the fuzzy geometric mean as follows:

$$
\begin{aligned}
& \tilde{\tilde{r}}_{i}=\left(\tilde{\tilde{a}}_{i 1} \otimes \tilde{\tilde{a}}_{i 2} \otimes \cdots \otimes \tilde{\tilde{a}}_{i n}\right)^{1 / n}, \\
& \text { where } \sqrt[n]{\tilde{\tilde{a}}_{i 1}}=\left(\begin{array}{l}
\left(\sqrt[n]{a_{i j 1}^{U}}, \sqrt[n]{a_{i j 2}^{U}}, \sqrt[n]{a_{i j 3}^{U}}, \sqrt[n]{a_{i j 4}^{U}} ; H_{1}\left(a_{i j}^{U}\right), H_{2}\left(a_{i j}^{U}\right)\right), \\
\left(\sqrt[n]{a_{i j 1}^{L}}, \sqrt[n]{a_{i j 2}^{L}}, \sqrt[n]{a_{i j 3}^{L}}, \sqrt[n]{a_{i j 4}^{L}} ; H_{1}\left(a_{i j}^{L}\right), H_{2}\left(a_{i j}^{L}\right)\right)
\end{array}\right) .
\end{aligned}
$$

Step 4. Calculate the fuzzy weights of each criterion using

$$
\tilde{\tilde{w}}_{i}=\tilde{\tilde{r}}_{i} \otimes\left(\tilde{\tilde{r}}_{1} \oplus \tilde{\tilde{r}}_{2} \oplus \cdots \oplus \tilde{\tilde{r}}_{n}\right)^{-1} \text {. }
$$

\subsection{Trapezoidal interval type- 2 fuzzy TOPSIS}

TOPSIS, developed by Hwang and Yoon (1981), is a simple ranking method in conception and application. The standard TOPSIS method attempts to choose alternatives that simultaneously have the shortest distance from the positive ideal solution and the farthest distance from the negative-ideal solution (Chen, Hwang 1992; Yoon, Hwang 1995; Behzadian et al. 2012; Celik et al. 2012). In this paper, we present trapezoidal interval type-2 fuzzy TOPSIS (TIT2FTOPSIS) method (Nasab, Rostamy-Malkhalifeh 2010; Chen, Lee 2010). The proposed TIT2FTOPSIS can be expressed in a series of steps:

Step 1. In the first step, assume that there is a set $X$ of alternatives, where $X=\left\{x_{1}, x_{2}, \ldots, x_{n}\right\}$, and assume that there is a set $F$ of criteria, $F=\left\{f_{1}, f_{2}, \ldots, f_{m}\right\}$ and there are $K$ experts $D=\left\{D_{1}, D_{2}, \ldots, D_{K}\right\}$. Each expert is a participant in our questionnaire and he has his own rating (performance value) on alternatives with respect to each criterion. Next, the aggregate rating (performance value) of alternatives with respect to each criterion can be calculated using Eq. (6):

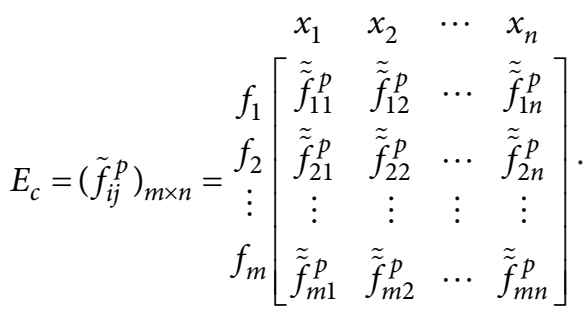


where $\tilde{\tilde{f}}_{i j}=\left(\frac{\tilde{\tilde{f}}_{i j}^{1} \oplus \tilde{\tilde{f}}_{i j}^{2} \oplus \cdots \oplus \tilde{\tilde{f}}_{i j}^{k}}{k}\right), \tilde{\tilde{f}}_{i j}$ is an interval type-2 fuzzy set $1 \leq i \leq m, 1 \leq j \leq n, 1 \leq c \leq k$ and $k$ denotes the number of decision-makers,

$\tilde{\tilde{f}}_{i j}=\left(\left(a_{i 1}^{U}, a_{i 2}^{U}, a_{i 3}^{U}, a_{i 4}^{U} ; H_{1}\left(\tilde{A}_{i}^{U}\right), H_{2}\left(\tilde{A}_{i}^{U}\right)\right),\left(a_{i 1}^{L}, a_{i 2}^{L}, a_{i 3}^{L}, a_{i 4}^{L} ; H_{1}\left(\tilde{A}_{i}^{L}\right), H_{2}\left(\tilde{A}_{i}^{L}\right)\right)\right)$.

Step 2. Construct the weighting matrix $W_{c}$ of the criteria and it is obtain by TIT2FAHP.

$$
\begin{aligned}
& \begin{array}{llll}
f_{1} & f_{2} & \cdots & f_{m}
\end{array} \\
& W_{c}=\left(\tilde{\tilde{w}}_{i}^{c}\right)_{1 \times m}=\left[\tilde{\tilde{w}}_{1}^{c}, \tilde{\tilde{w}}_{2}^{c}, \cdots, \tilde{\tilde{w}}_{m}^{c}\right] \text {, }
\end{aligned}
$$

where $\tilde{\tilde{w}}_{i}$ is an interval type-2 fuzzy set $1 \leq i \leq m, 1 \leq j \leq n$.

Step 3. Considering the different weights of each criterion, the weighted decision matrix

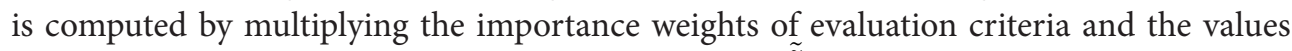
in the decision matrix. The weighted decision matrix $\tilde{\tilde{V}}$ for each criterion is defined as:

$$
\tilde{\tilde{v}}_{i j}=\tilde{\tilde{r}}_{i j} \mathrm{x} \tilde{\tilde{w}}_{i},
$$

where $\tilde{v}_{i j}$ denotes the weighted trapezoidal interval type-2 fuzzy numbers.

Step 4. Determine the fuzzy positive ideal solution $\left(v^{*}\right)$ and the fuzzy negative ideal solution $\left(v^{-}\right)$:

$$
\begin{aligned}
& v^{*}= \begin{cases}(1,1,1,1,1,1), & \text { for benefit criteria, } \\
(0,0,0,0,1,1), & \text { for cost criteria. }\end{cases} \\
& v^{-}= \begin{cases}(0,0,0,0,1,1), & \text { for benefit criteria, } \\
(1,1,1,1,1,1), & \text { for cost criteria. }\end{cases}
\end{aligned}
$$

Step 5. Calculate the separation measures using Euclidean distance. The separation of each alternative from the fuzzy positive ideal solution is given as,

where

$$
d^{U^{*}}\left(x_{j}\right)=\sum_{i=1}^{m} d^{U^{*}}\left(\tilde{v}^{*}, \tilde{v}_{i j}^{U}\right), d^{L^{*}}\left(x_{j}\right)=\sum_{i=1}^{m} d^{L^{*}}\left(\tilde{v}^{*}, \tilde{v}_{i j}^{L}\right),
$$

$$
\begin{aligned}
& \tilde{v}_{i j}=\left(\tilde{v}_{i j}^{U}, \tilde{v}_{i j}^{L}\right)=\left(\left(v_{i j}^{1 U}, v_{i j}^{2 U} v_{i j}^{3 U}, v_{i j}^{4 U} ; H_{1}\left(\tilde{v}_{i j}^{U}\right), H_{2}\left(\tilde{v}_{i j}^{U}\right)\right),\left(v_{i j}^{1 L}, v_{i j}^{2 L} v_{i j}^{3 L}, v_{i j}^{4 L} ; H_{1}\left(\tilde{v}_{i j}^{L}\right), H_{2}\left(\tilde{v}_{i j}^{L}\right)\right)\right) ; \\
& d^{U^{*}}\left(\tilde{v}^{*}, \tilde{v}_{i j}^{U}\right)=\sqrt{\frac{1}{4} \sum_{k=1}^{4}\left(v_{i j}^{k U}-v^{*}\right)}, d^{L^{*}}\left(\tilde{v}^{*}, \tilde{v}_{i j}^{L}\right)=\sqrt{\frac{1}{4} \sum_{k=1}^{4}\left(v_{i j}^{k L}-v^{*}\right)} .
\end{aligned}
$$

Similarly, the separation from the fuzzy negative ideal solution is given as,

$$
\begin{gathered}
d^{U-}\left(x_{j}\right)=\sum_{i=1}^{m} d^{U-}\left(\tilde{v}^{-}, \tilde{v}_{i j}^{U}\right), d^{L-}\left(x_{j}\right)=\sum_{i=1}^{m} d^{L-}\left(\tilde{v}^{-}, \tilde{v}_{i j}^{L}\right), \\
d^{U-}\left(\tilde{v}^{-}, \tilde{v}_{i j}^{U}\right)=\sqrt{\frac{1}{4} \sum_{k=1}^{4}\left(v_{i j}^{k U}-v^{-}\right)}, d^{L-}\left(\tilde{v}^{-}, \tilde{v}_{i j}^{L}\right)=\sqrt{\frac{1}{4} \sum_{k=1}^{4}\left(v_{i j}^{k L}-v^{-}\right)} .
\end{gathered}
$$


Step 6. Then the closeness coefficient $C C\left(x_{j}\right)$ is determined.

$$
\begin{gathered}
C C\left(x_{j}\right)=\frac{C C_{1}\left(x_{j}\right)+C C_{2}\left(x_{j}\right)}{2}, \\
C C_{1}\left(x_{j}\right)=\frac{d^{U-}\left(x_{j}\right)}{d^{U^{*}}\left(x_{j}\right)+d^{U-}\left(x_{j}\right)}, C C_{2}\left(x_{j}\right)=\frac{d^{L-}\left(x_{j}\right)}{d^{L^{*}}\left(x_{j}\right)+d^{L-}\left(x_{j}\right)} .
\end{gathered}
$$

Step 7. The alternatives can be ranked in decreasing order. The larger the value of $C C\left(x_{j}\right)$, is the higher the preference of the alternative.

\section{The preparedness and response ability evaluation of non-governmental organizations}

Here, we present an empirical case to evaluate the performances of NGOs in Turkey. The aim of the case is to show the applicability and advantages of the proposed technique. Four prominent NGOs which serve in Turkey are selected to evaluate their emergency preparedness and response capability. These NGOs are listed alphabetically as Deniz Feneri Association (The Lighthouse Association), Kimse Yok Mu Association (Is Anybody There?), İnsani Yardım Vakfı (IHH) (The Foundation for Human Rights and Freedoms and Humanitarian Relief) and Yardımeli Association (Helping Hand Association). Deniz Feneri Association implements humanitarian projects in 47 countries in Africa, Asia, Balkans, and Middle East. It is a prominent NGO with its international aid activities, too. Kimse Yok Mu Association categorizes its field of works as follows: aid for disasters, aid for health, aid for education, aid in Bairams, individual aid campaigns, aid for Africa and sister family aids. IHH aims to deliver humanitarian relief to all people who are suffering as a result of crises, wars or natural disasters, in the possible quickest way. Yardımeli Association aims to restore the environment and deliver humanitarian relief. We only mention the names of NGOs here because of privacy. In the final ranking, we use $\mathrm{NGO}_{1}, \mathrm{NGO}_{2}, \mathrm{NGO}_{3}$ and $\mathrm{NGO}_{4}$ for each NGO without giving their names.

The survey was conducted between May 2013 and September 2013 via online and face to face. Among the 50 surveys, 32 were returned for a return rate of $64 \%$. The evaluation of NGOs' performances is done by totally 32 experts. The survey about evaluation of NGOs' performances was mainly composed of three sections. The first was about the user characteristics. The user characteristics questions which are asked to experts, who are directly related with NGOs in Turkey, are detailed in Table 3. There are only 3 female experts of the 32 experts. Most of the sample is older than 25 years old and 25\% of the respondents are academicians, $56 \%$ are logisticians and $6 \%$ are logistics managers. About $60 \%$ of the experts' experiences are smaller than seven years. Only two of them have fifteen years and above experiences.

The second section contains questions for evaluating the relative importances of criteria, and respondents were asked to indicate the perceived importance weights of each CSF by asking pair wise comparison using nine point scales from absolutely strong to absolutely weak (it is shown in Table 2). In this part, there are sixty different comparisons for the 
pair wise comparison of the main and sub-criteria within the context of CFSs. In the last section, the NGOs' performance evaluations with respect to each CSF are asked for each expert using seven point scales from very low to very high. There are one hundred questions and each expert assessed all of the four NGOs with respect to each CSF.

In this study, a novel methodology that integrates TIT2FAHP and TIT2FTOPSIS approaches is proposed. In this methodology, the importance weights of each CSF are determined by TIT2FAHP and then the preparedness and response abilities of NGOs to a disaster are evaluated via TIT2FTOPSIS approach. Figure 2 shows the details and flow of the proposed methodology. This methodology can be applied to any complex decision making problem which encounters imprecise, indefinite, and subjective data or vague information; as proved by sensitivity analysis.

The hierarchical structure of evaluation criteria and sub-criteria within the context of CFSs, which have determined in Section 2 and the NGOs is shown in Figure 3. Trapezoidal interval type-2 fuzzy pair wise comparison matrix for all sub-criteria among in the hierarchical structure is constructed by using Eq. (1). Then, the consistency ratio is calculated (Eqs (2)-(3)) and it is shown in Table 4 for all main and sub-criteria. Consistency ratio for each sub-criterion is less than 0.1 . Therefore, the comparison results can be considered as consistent. The fuzzy geometric mean of the criteria is obtained in Step 3 using Eq. (4). In the last step of the TIT2FAHP, the fuzzy weight of each CSF is calculated using Eq. (5) and it is shown in Table 4.

Table 3. The demographic information of respondents

\begin{tabular}{lccc}
\hline Question & Option & Number observed & Percentage \\
\hline \multirow{3}{*}{ Educational levels } & No. of invalid survey & 18 & $36 \%$ \\
& No. of valid survey & 32 & $64 \%$ \\
\hline \multirow{3}{*}{ Expertise Area } & High School & 14 & $44 \%$ \\
& College/University & 10 & $31 \%$ \\
& MSc/PhD & 8 & $25 \%$ \\
\hline \multirow{3}{*}{ Age (years) } & Academician & 8 & $25 \%$ \\
& Logistician & 18 & $56 \%$ \\
& Logistics Manager & 6 & $19 \%$ \\
\hline Gender & $15-25$ & 5 & $16 \%$ \\
& $25-35$ & 11 & $34 \%$ \\
& $35-45$ & 13 & $41 \%$ \\
& $45+$ & 3 & $9 \%$ \\
\hline \multirow{2}{*}{ Experience } & Male & 29 & $91 \%$ \\
& Female & 3 & $9 \%$ \\
\hline
\end{tabular}




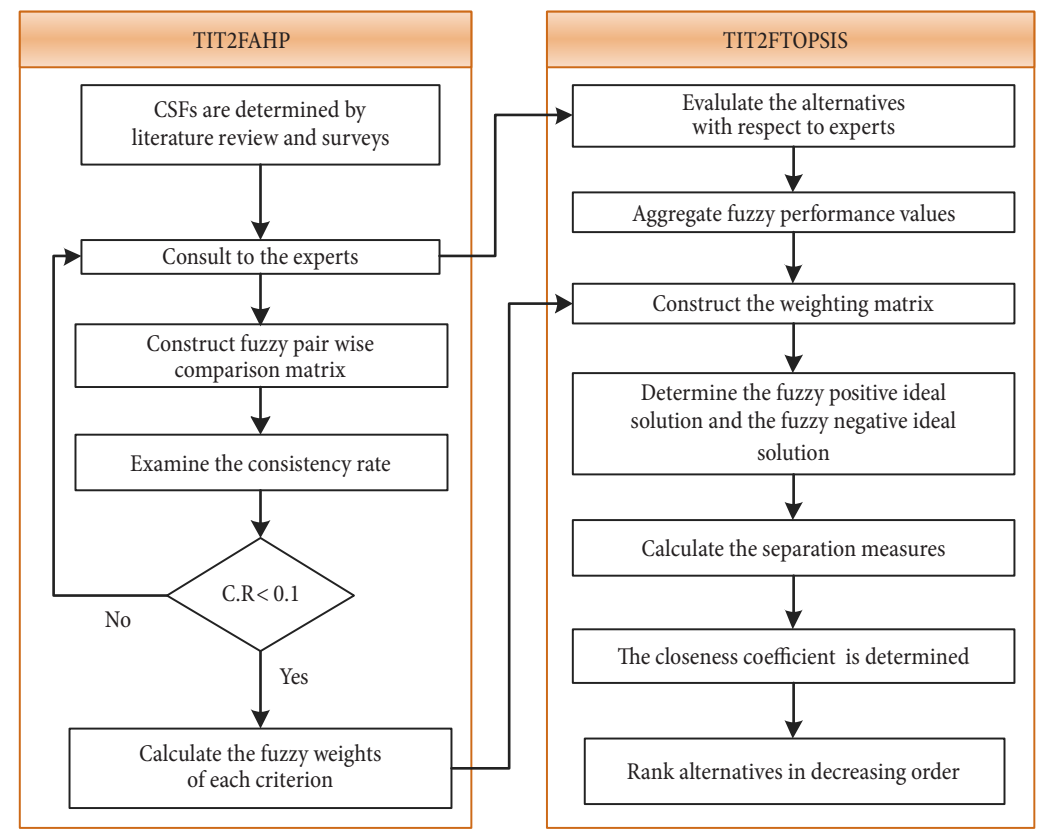

Fig. 2. The proposed hybrid TIT2FAHP and TIT2FTOPSIS methodology

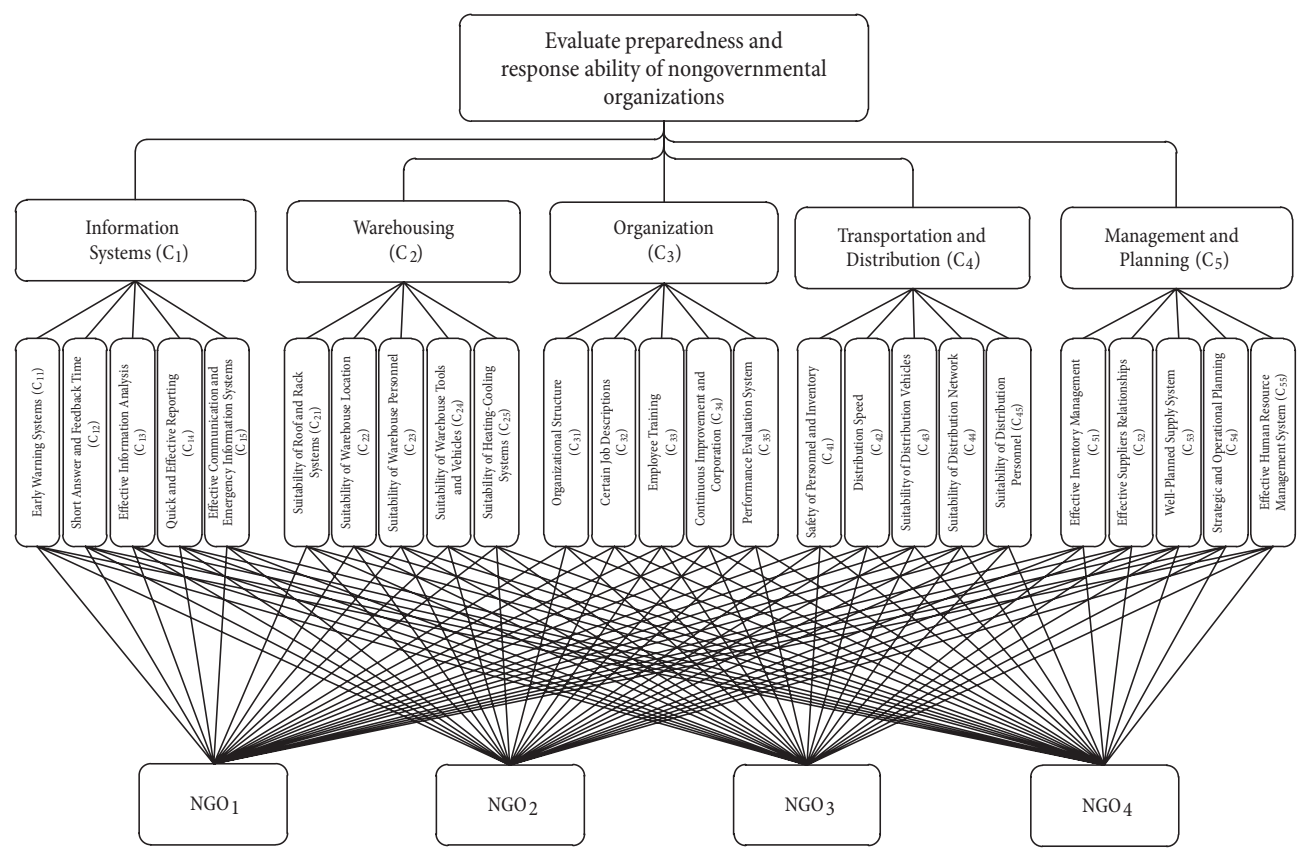

Fig. 3. The hierarchical structure 
Table 4. Type-2 fuzzy weights obtained with TIT2FAHP

\begin{tabular}{|c|c|c|c|}
\hline Criteria & Sub-criteria & Trapezoidal interval type- 2 fuzzy weights & Consistency ratio \\
\hline $\mathrm{C}_{1}$ & & $((0.05 ; 0.08 ; 0.08 ; 0.13 ; 1 ; 1),(0.06 ; 0.08 ; 0.08 ; 0.11 ; 0.9 ; 0.9))$ & \multirow{5}{*}{0.045} \\
\hline $\mathrm{C}_{2}$ & & $((0.09 ; 0.15 ; 0.15 ; 0.26 ; 1 ; 1),(0.1 ; 0.15 ; 0.15 ; 0.23 ; 0.9 ; 0.9))$ & \\
\hline $\mathrm{C}_{3}$ & & $((0.04 ; 0.06 ; 0.06 ; 0,1 ; 1 ; 1),(0.04 ; 0.06 ; 0.06 ; 0.08 ; 0.9 ; 0.9))$ & \\
\hline $\mathrm{C}_{4}$ & & $((0.19 ; 0.29 ; 0.29 ; 0.47 ; 1 ; 1),(0.2 ; 0.29 ; 0.29 ; 0.41 ; 0.9 ; 0.9))$ & \\
\hline $\mathrm{C}_{5}$ & & $((0.25 ; 0.41 ; 0.41 ; 0.66 ; 1 ; 1),(0.29 ; 0.41 ; 0.41 ; 0.63 ; 0.9 ; 0.9))$ & \\
\hline \multirow{5}{*}{$\mathrm{C}_{1}$} & $\mathrm{C}_{11}$ & $((0.34 ; 0.5 ; 0.5 ; 0.72 ; 1 ; 1),(0.38 ; 0.5 ; 0.5 ; 0.68 ; 0.9 ; 0.9))$ & \multirow{5}{*}{0.003} \\
\hline & $\mathrm{C}_{12}$ & $((0.14 ; 0.19 ; 0.19 ; 0.28 ; 1 ; 1),(0.14 ; 0.19 ; 0.19 ; 0.25 ; 0.9 ; 0.9))$ & \\
\hline & $\mathrm{C}_{13}$ & $((0.03 ; 0.04 ; 0.04 ; 0.06 ; 1 ; 1),(0.03 ; 0.04 ; 0.04 ; 0.05 ; 0.9 ; 0.9))$ & \\
\hline & $\mathrm{C}_{14}$ & $((0.05 ; 0.08 ; 0.08 ; 0.12 ; 1 ; 1),(0.05 ; 0.08 ; 0.08 ; 0.1 ; 0.9 ; 0.9))$ & \\
\hline & $\mathrm{C}_{15}$ & $((0.14 ; 0.19 ; 0.19 ; 0.28 ; 1 ; 1),(0.14 ; 0.19 ; 0.19 ; 0.25 ; 0.9 ; 0.9))$ & \\
\hline \multirow{5}{*}{$\mathrm{C}_{2}$} & $\mathrm{C}_{21}$ & $((0.19 ; 0.29 ; 0.29 ; 0.44 ; 1 ; 1),(0.21 ; 0.29 ; 0.29 ; 0.38 ; 0.9 ; 0.9))$ & \multirow{5}{*}{0.085} \\
\hline & $\mathrm{C}_{22}$ & $((0.31 ; 0.47 ; 0.47 ; 0.69 ; 1 ; 1),(0.36 ; 0.47 ; 0.47 ; 0.65 ; 0.9 ; 0.9))$ & \\
\hline & $\mathrm{C}_{23}$ & $((0.08 ; 0.12 ; 0.12 ; 0.18 ; 1 ; 1),(0.09 ; 0.12 ; 0.12 ; 0.15 ; 0.9 ; 0.9))$ & \\
\hline & $\mathrm{C}_{24}$ & $((0.05 ; 0.08 ; 0.08 ; 0.13 ; 1 ; 1),(0.06 ; 0.08 ; 0.08 ; 0.11 ; 0.9 ; 0.9))$ & \\
\hline & $\mathrm{C}_{25}$ & $((0.03 ; 0.04 ; 0.04 ; 0.07 ; 1 ; 1),(0.03 ; 0.04 ; 0.04 ; 0.05 ; 0.9 ; 0.9))$ & \\
\hline \multirow{5}{*}{$\mathrm{C}_{3}$} & $\mathrm{C}_{31}$ & $((0.31 ; 0.47 ; 0.47 ; 0.69 ; 1 ; 1),(0.36 ; 0.47 ; 0.47 ; 0.65 ; 0.9 ; 0.9))$ & \multirow{5}{*}{0.022} \\
\hline & $\mathrm{C}_{32}$ & $((0.03 ; 0.05 ; 0.05 ; 0.07 ; 1 ; 1),(0.03 ; 0.05 ; 0.05 ; 0.06 ; 0.9 ; 0.9))$ & \\
\hline & $\mathrm{C}_{33}$ & $((0.14 ; 0.2 ; 0.2 ; 0.3 ; 1 ; 1),(0.15 ; 0.2 ; 0.2 ; 0.27 ; 0.9 ; 0.9))$ & \\
\hline & $\mathrm{C}_{34}$ & $((0.14 ; 0.2 ; 0.2 ; 0.3 ; 1 ; 1),(0.15 ; 0.2 ; 0.2 ; 0.27 ; 0.9 ; 0.9))$ & \\
\hline & $\mathrm{C}_{35}$ & $((0.05 ; 0.08 ; 0.08 ; 0.12 ; 1 ; 1),(0.06 ; 0.08 ; 0.08 ; 0.1 ; 0.9 ; 0.9))$ & \\
\hline \multirow{5}{*}{$\mathrm{C}_{4}$} & $\mathrm{C}_{41}$ & $((0.24 ; 0.35 ; 0.35 ; 0.49 ; 1 ; 1),(0.27 ; 0.35 ; 0.35 ; 0.47 ; 0.9 ; 0.9))$ & \multirow{5}{*}{0.060} \\
\hline & $\mathrm{C}_{42}$ & $((0.22 ; 0.33 ; 0.33 ; 0.46 ; 1 ; 1),(0.25 ; 0.33 ; 0.33 ; 0.44 ; 0.9 ; 0.9))$ & \\
\hline & $\mathrm{C}_{43}$ & $((0.07 ; 0.1 ; 0.1 ; 0.16 ; 1 ; 1),(0.07 ; 0.1 ; 0.1 ; 0.13 ; 0.9 ; 0.9))$ & \\
\hline & $\mathrm{C}_{44}$ & $((0.03 ; 0.04 ; 0.04 ; 0.05 ; 1 ; 1),(0.03 ; 0.04 ; 0.04 ; 0.04 ; 0.9 ; 0.9))$ & \\
\hline & $\mathrm{C}_{45}$ & $((0.13 ; 0.19 ; 0.19 ; 0.29 ; 1 ; 1),(0.13 ; 0.19 ; 0.19 ; 0.24 ; 0.9 ; 0.9))$ & \\
\hline \multirow{5}{*}{$\mathrm{C}_{5}$} & $\mathrm{C}_{51}$ & $((0.12 ; 0.18 ; 0.18 ; 0.27 ; 1 ; 1),(0.13 ; 0.18 ; 0.18 ; 0.25 ; 0.9 ; 0.9))$ & \multirow{5}{*}{0.068} \\
\hline & $\mathrm{C}_{52}$ & $((0.03 ; 0.04 ; 0.04 ; 0.06 ; 1 ; 1),(0.03 ; 0.04 ; 0.04 ; 0.05 ; 0.9 ; 0.9))$ & \\
\hline & $\mathrm{C}_{53}$ & $((0.05 ; 0.07 ; 0.07 ; 0.11 ; 1 ; 1),(0.06 ; 0.07 ; 0.07 ; 0.09 ; 0.9 ; 0.9))$ & \\
\hline & $\mathrm{C}_{54}$ & $((0.3 ; 0.46 ; 0.46 ; 0.66 ; 1 ; 1),(0.35 ; 0.46 ; 0.46 ; 0.63 ; 0.9 ; 0.9))$ & \\
\hline & $\mathrm{C}_{55}$ & $((0.18 ; 0.25 ; 0.25 ; 0.35 ; 1 ; 1),(0.19 ; 0.25 ; 0.25 ; 0.3 ; 0.9 ; 0.9))$ & \\
\hline
\end{tabular}

The related linguistic terms to describe the importance of NGOs with respect to CSFs are shown in Table 5, and assessed by the experts as seen in Table 6. For example, $\mathrm{NGO}_{1}$ is evaluated with respect to $C_{11}$ as very low by 8 experts, low by 3 experts, medium low by 5 experts, medium by 4 experts, medium high by 7 experts, high by 3 experts, and very high by 2 experts (shown in Table 6, row 3 and columns 3-9). The all evaluations for four NGOs with respect to all CSFs are presented in the same manner, in Table 6. Then, the linguistic evaluations are converted into trapezoidal interval type- 2 fuzzy numbers. The aggregated matrix for NGOs' ratings is calculated by using Eq. (6), and it is shown in Table 7. Hence, the weighted fuzzy decision matrix is calculated by multiplying the aggregated fuzzy 
performance values of NGOs with fuzzy weights using Eq. (8), which is obtained by TIT2FAHP (Table 8). The fuzzy positive ideal solution and the fuzzy negative ideal solution for beneficial criteria are determined by using Eqs ((9)-(10)).

Table 5. Linguistic terms and their corresponding interval type-2 fuzzy sets

\begin{tabular}{ll}
\hline \multicolumn{1}{c}{ Linguistics Terms } & \multicolumn{1}{c}{ Interval type-2 fuzzy sets } \\
\hline Very Low $(\mathrm{VL})$ & $((0 ; 0 ; 0 ; 0,1 ; 1 ; 1),(0 ; 0 ; 0 ; 0.05 ; 0.9 ; 0.9))$ \\
\hline Low $(\mathrm{L})$ & $((0 ; 0.1 ; 0.1 ; 0.3 ; 1 ; 1),(0.05 ; 0.1 ; 0.1 ; 0.2 ; 0.9 ; 0.9))$ \\
\hline Medium Low $(\mathrm{ML})$ & $((0.1 ; 0.3 ; 0.3 ; 0.5 ; 1 ; 1),(0.1 ; 0.3 ; 0.3 ; 0.5 ; 0.9 ; 0.9))$ \\
\hline Medium (M) & $((0.3 ; 0.5 ; 0.5 ; 0.7 ; 1 ; 1),(0.5 ; 0.5 ; 0.5 ; 0.6 ; 0.9 ; 0.9))$ \\
\hline Medium High (MH) & $((0.5 ; 0.7 ; 0.7 ; 0.9 ; 1 ; 1),(0.5 ; 0.7 ; 0.7 ; 0.9 ; 0.9 ; 0.9))$ \\
\hline High (H) & $((0.7 ; 0.9 ; 0.9 ; 1 ; 1 ; 1),(0.8 ; 0.9 ; 0.9 ; 0.95 ; 0.9 ; 0.9))$ \\
\hline Very High $(\mathrm{VH})$ & $((0.9 ; 1 ; 1 ; 1 ; 1 ; 1),(0.95 ; 1 ; 1 ; 1 ; 0.9 ; 0.9))$ \\
\hline
\end{tabular}

Table 6. Expert evaluation scores of the NGOs alternatives

\begin{tabular}{|c|c|c|c|c|c|c|c|c|c|c|c|c|c|c|c|c|c|c|c|c|c|c|c|c|c|c|c|c|c|}
\hline & & \multicolumn{7}{|c|}{$\mathrm{NGO}_{1}$} & \multicolumn{7}{|c|}{$\mathrm{NGO}_{2}$} & \multicolumn{7}{|c|}{$\mathrm{NGO}_{3}$} & \multicolumn{7}{|c|}{$\mathrm{NGO}_{4}$} \\
\hline & & VL & & & & & & & VL & $\mathrm{L}$ & ML & & & & $\mathrm{VH}$ & VL & $\mathrm{L}$ & ML & & $\mathrm{MH}$ & & $\mathrm{VH}$ & VL & $\mathrm{L}$ & ML & & MH & & $\mathrm{VH}$ \\
\hline \multirow{5}{*}{$\mathrm{C}_{1}$} & $\mathrm{C}_{11}$ & 8 & 3 & 5 & 4 & 7 & 3 & 2 & 2 & 3 & 5 & 7 & 6 & 4 & 5 & 2 & 4 & 3 & 5 & 7 & 3 & 8 & 8 & 6 & 5 & 7 & 4 & 2 & 0 \\
\hline & $\mathrm{C}_{12}$ & 7 & 5 & 4 & 3 & 6 & 5 & 2 & 8 & 4 & 3 & 4 & 5 & 3 & 5 & 4 & 3 & 7 & 5 & 5 & 4 & 4 & 7 & 6 & 7 & 4 & 6 & 1 & 1 \\
\hline & $\mathrm{C}_{13}$ & 3 & 5 & 5 & 7 & 5 & 3 & 4 & 4 & 5 & 7 & 4 & 5 & 2 & 5 & 2 & 5 & 7 & 6 & 2 & 2 & 8 & 8 & 6 & 9 & 4 & 2 & 2 & 1 \\
\hline & $\mathrm{C}_{14}$ & 5 & 4 & 8 & 3 & 2 & 5 & 5 & 4 & 8 & 4 & 2 & 5 & 5 & 4 & 2 & 3 & 5 & 2 & 8 & 7 & 5 & 7 & 6 & 8 & 3 & 2 & 4 & 2 \\
\hline & $\mathrm{C}_{15}$ & 5 & 7 & 2 & 6 & 8 & 2 & 2 & 4 & 5 & 5 & 6 & 5 & 5 & 2 & 2 & 4 & 6 & 4 & 5 & 5 & 6 & 4 & 7 & 6 & 8 & 4 & 1 & 2 \\
\hline \multirow{5}{*}{$\mathrm{C}_{2}$} & $\mathrm{C}_{21}$ & 6 & 5 & 7 & 2 & 3 & 4 & 5 & 2 & 8 & 2 & 7 & 5 & 4 & 4 & 3 & 5 & 2 & 8 & 5 & 6 & 3 & 5 & 4 & 6 & 6 & 2 & 4 & 5 \\
\hline & $\mathrm{C}_{22}$ & 4 & 5 & 8 & 3 & 2 & 7 & 3 & 4 & 3 & 6 & 5 & 6 & 7 & 1 & 4 & 5 & 5 & 3 & 2 & 5 & 8 & 7 & 6 & 9 & 4 & 3 & 2 & 3 \\
\hline & $\mathrm{C}_{23}$ & 4 & 6 & 7 & 5 & 5 & 3 & 2 & 7 & 5 & 4 & 5 & 3 & 4 & 4 & 6 & 5 & 5 & 7 & 0 & 2 & 7 & 3 & 8 & 6 & 7 & 2 & 3 & 3 \\
\hline & $\mathrm{C}_{24}$ & 5 & 6 & 4 & 7 & 6 & 2 & 2 & 5 & 6 & 4 & 7 & 5 & 3 & 2 & 5 & 4 & 2 & 6 & 5 & 7 & 3 & 9 & 5 & 5 & 3 & 4 & 4 & 2 \\
\hline & $\mathrm{C}_{25}$ & 2 & 5 & 8 & 2 & 9 & 4 & 2 & 2 & 5 & 8 & 5 & 4 & 5 & 3 & 2 & 2 & 8 & 4 & 9 & 2 & 5 & 8 & 7 & 7 & 4 & 3 & 1 & 2 \\
\hline \multirow{5}{*}{$\mathrm{C}_{3}$} & $\mathrm{C}_{31}$ & 7 & 5 & 7 & 4 & 3 & 2 & 4 & 4 & 6 & 7 & 5 & 3 & 6 & 1 & 4 & 5 & 8 & 7 & 1 & 1 & 6 & 2 & 8 & 9 & 5 & 2 & 5 & 1 \\
\hline & $\mathrm{C}_{32}$ & 4 & 5 & 8 & 3 & 2 & $\gamma$ & 3 & 2 & 5 & 5 & 4 & 6 & 5 & 5 & 1 & 1 & 8 & 7 & 9 & 2 & 4 & 8 & 5 & 9 & 3 & 4 & 2 & 1 \\
\hline & $\mathrm{C}_{33}$ & 7 & 5 & 6 & 2 & 7 & 3 & 2 & 4 & 7 & 3 & 5 & 5 & 6 & 2 & 4 & 4 & 7 & 3 & 6 & 6 & 2 & 5 & 6 & 7 & 5 & 3 & 2 & 4 \\
\hline & $\mathrm{C}_{34}$ & 3 & 5 & 8 & 4 & 2 & 5 & 5 & 5 & 2 & 4 & 6 & 6 & 5 & 5 & 2 & 2 & 8 & 4 & 8 & 2 & 6 & 9 & 1 & 11 & 2 & 3 & 2 & 4 \\
\hline & $\mathrm{C}_{35}$ & 5 & 2 & 7 & 5 & 6 & 3 & 4 & 4 & 3 & 5 & 2 & 7 & 6 & 5 & 4 & 5 & 2 & 6 & 5 & 7 & 3 & 4 & 8 & 8 & 6 & 5 & 1 & 0 \\
\hline \multirow{5}{*}{$\mathrm{C}_{4}$} & $\mathrm{C}_{41}$ & 5 & 5 & 8 & 3 & 1 & 4 & 6 & 5 & 4 & 3 & 8 & 8 & 0 & 4 & 2 & 4 & 5 & 3 & 8 & 4 & 6 & 11 & 5 & 8 & 4 & 2 & 0 & 2 \\
\hline & $\mathrm{C}_{42}$ & 5 & 8 & 2 & 6 & 7 & 2 & 2 & 4 & 8 & 2 & 6 & 7 & 5 & 0 & 5 & 4 & 3 & 2 & 8 & 8 & 2 & 7 & 8 & 5 & 5 & 4 & 3 & 0 \\
\hline & $\mathrm{C}_{43}$ & 4 & 8 & 5 & 2 & 7 & 4 & 2 & 5 & 5 & 6 & 4 & 9 & 3 & 0 & 2 & 2 & 5 & 6 & 8 & 9 & 0 & 5 & 6 & 5 & 10 & 2 & 2 & 2 \\
\hline & $\mathrm{C}_{44}$ & 5 & 4 & 7 & 8 & 6 & 2 & 0 & 4 & 5 & 6 & 5 & 5 & 7 & 0 & 3 & 3 & 7 & 6 & 5 & 5 & 3 & 11 & 2 & 8 & 7 & 2 & 2 & 0 \\
\hline & $\mathrm{C}_{45}$ & 4 & 5 & 8 & 5 & 1 & 5 & 4 & 5 & 4 & 5 & 3 & 5 & 8 & 0 & 2 & 4 & 4 & 6 & 8 & 2 & 6 & 12 & 5 & 7 & 2 & 2 & 2 & 2 \\
\hline \multirow{5}{*}{$\mathrm{C}_{5}$} & $\mathrm{C}_{51}$ & 3 & 5 & 4 & 6 & 8 & 4 & 2 & 2 & 5 & 7 & 5 & 5 & 6 & 2 & 2 & 1 & 4 & 7 & 8 & 5 & 5 & 2 & 4 & 7 & 8 & 10 & 1 & 0 \\
\hline & $\mathrm{C}_{52}$ & 5 & 5 & 8 & 9 & 3 & 2 & 0 & 7 & 5 & 6 & 5 & 7 & 1 & 1 & 5 & 4 & 8 & 7 & 6 & 1 & 1 & 8 & 2 & 5 & 7 & 3 & 5 & 2 \\
\hline & $\mathrm{C}_{53}$ & 9 & 5 & 2 & 1 & 7 & 5 & 3 & 8 & 4 & 5 & 2 & 6 & 5 & 2 & 4 & 5 & 3 & 4 & 7 & 5 & 4 & 8 & 8 & 6 & 4 & 4 & 2 & 0 \\
\hline & $\mathrm{C}_{54}$ & 7 & 5 & 3 & 5 & 4 & 6 & 2 & 8 & 2 & 6 & 4 & 5 & 2 & 5 & 5 & 5 & 2 & 1 & 8 & 6 & 5 & 9 & 9 & 2 & 7 & 4 & 0 & 1 \\
\hline & $\mathrm{C}_{55}$ & 6 & 3 & 5 & 5 & 7 & 2 & 4 & 5 & 6 & 3 & 2 & 6 & 8 & 2 & 3 & 2 & 2 & 7 & 8 & 5 & 5 & 2 & 1 & 13 & 4 & 7 & 5 & 0 \\
\hline
\end{tabular}



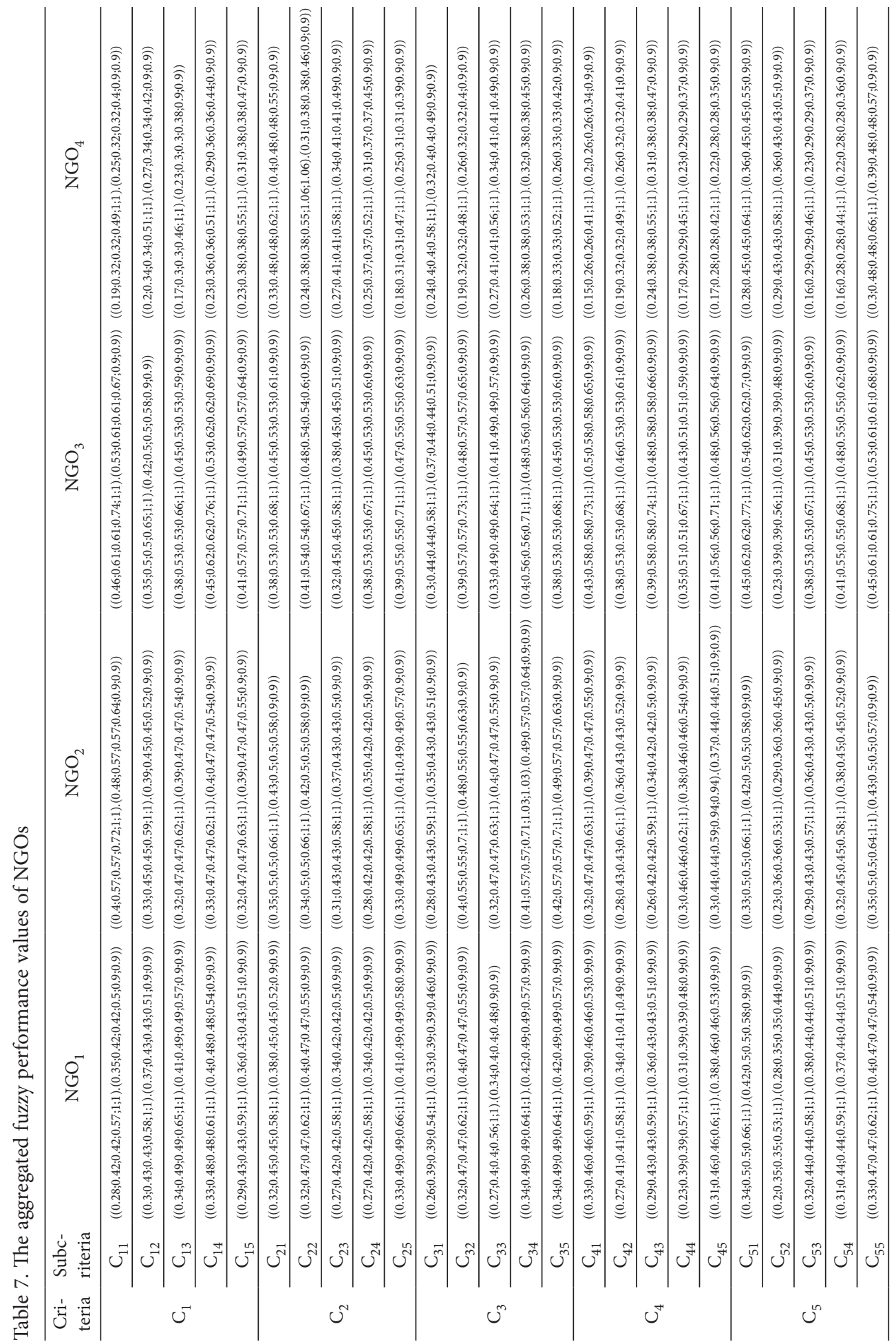


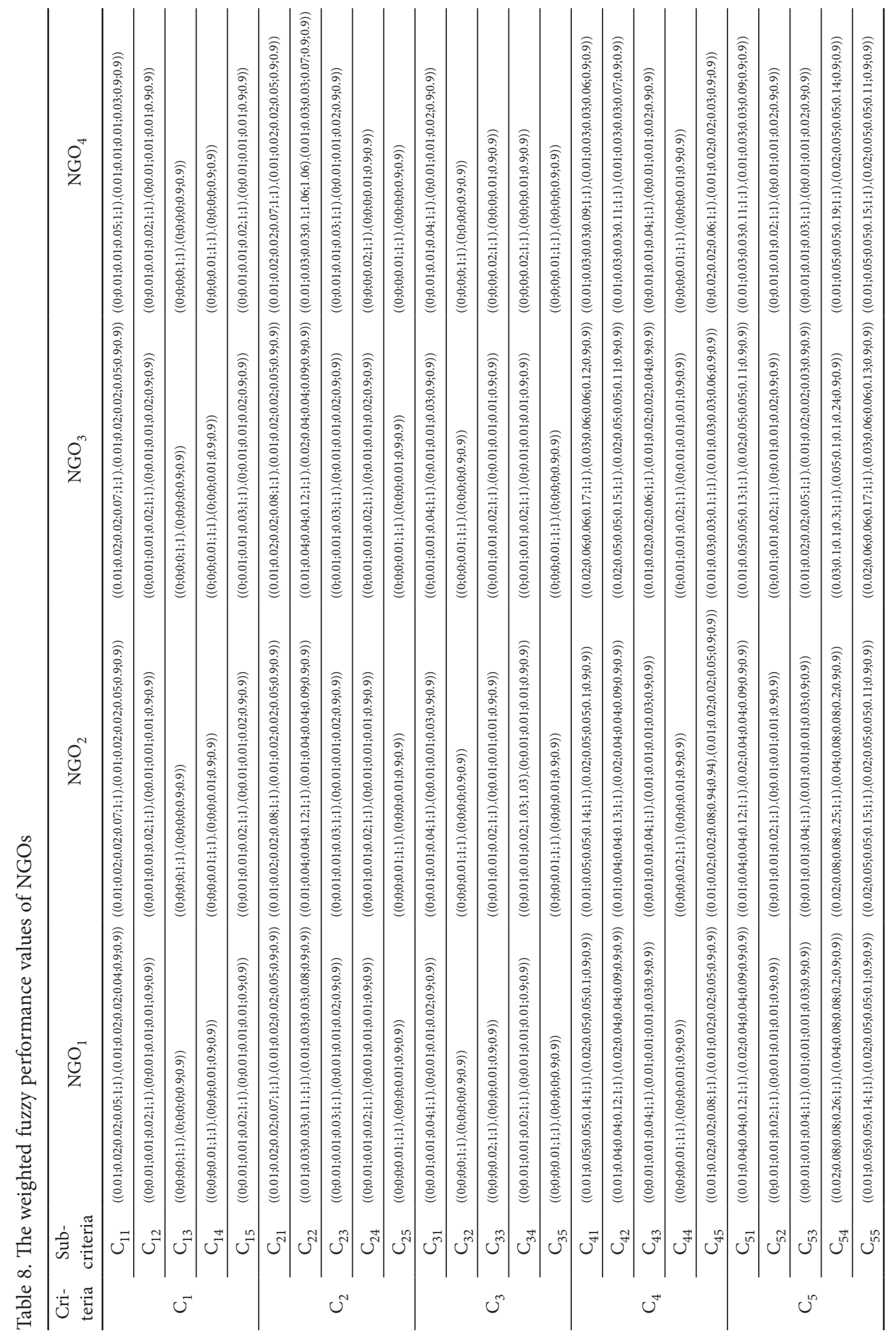


Table 9 illustrates the separation from the ideal and negative-ideal solutions for each NGO by using Eqs (11)-(12), respectively. Next, the closeness coefficient is calculated and the results are presented in Table 10.

Table 9.The separation measure of each alternative and the closeness coefficient

\begin{tabular}{ccccc}
\hline & $d^{U^{*}}\left(x_{j}\right)$ & $d^{L^{*}}\left(x_{j}\right)$ & $d^{U-}\left(x_{j}\right)$ & $d^{L-}\left(x_{j}\right)$ \\
\hline $\mathrm{NGO}_{1}$ & 24.4026 & 24.4811 & 0.7756 & 0.6027 \\
\hline $\mathrm{NGO}_{2}$ & 24.3769 & 24.4578 & 0.8074 & 0.6289 \\
\hline $\mathrm{NGO}_{3}$ & 24.2814 & 24.3637 & 0.9176 & 0.7329 \\
\hline $\mathrm{NGO}_{4}$ & 24.5043 & 24.5818 & 0.6608 & 0.4925 \\
\hline
\end{tabular}

Table 10. The closeness coefficient

\begin{tabular}{cccc}
\hline & $\mathrm{CC}_{1}\left(x_{j}\right)$ & $\mathrm{CC}_{2}\left(x_{j}\right)$ & $\mathrm{CC}\left(x_{j}\right)$ \\
\hline $\mathrm{NGO}_{1}$ & 0.0308 & 0.0240 & 0.0274 \\
\hline $\mathrm{NGO}_{2}$ & 0.0321 & 0.0251 & 0.0286 \\
\hline $\mathrm{NGO}_{3}$ & 0.0364 & 0.0292 & 0.0328 \\
\hline $\mathrm{NGO}_{4}$ & 0.0263 & 0.0196 & 0.0229 \\
\hline
\end{tabular}

Finally, according to the closeness coefficients of the four NGOs, we obtain the priority sequence of NGOs as; $\mathrm{NGO}_{3}>\mathrm{NGO}_{2}>\mathrm{NGO}_{1}>\mathrm{NGO}_{4}$. $\mathrm{NGO}_{3}$ is determined to have the best preparedness and response ability rank in case of disaster. However there are several criteria need to be improved in order to increase preparedness and response ability level for $\mathrm{NGO}_{3}$. Effective human resource management system and certain job descriptions criteria are needed to be revised. $\mathrm{NGO}_{2}$ should focus on the warehousing and transportation and distribution criteria. The possible improvements in these criteria will provide a better preparedness and response ability and contribute significantly to their performances. $\mathrm{NGO}_{1}$ should also improve information systems and warehousing criteria. $\mathrm{NGO}_{4}$ is the worst one considering preparedness and response ability. For $\mathrm{NGO}_{4}$, the major criteria that decrease preparedness and response ability levels are information systems, management and planning, organization. To increase preparedness and response ability, $\mathrm{NGO}_{4}$ has to improve these major criteria.

\subsection{Sensitivity analysis}

Sensitivity analysis is applied to evaluate emergency preparedness and response ability performances of NGOs to a disaster by changing the weights of main criteria mutually. For example, if the weights of information systems $\left(\mathrm{C}_{1}\right)$ and warehousing $\left(\mathrm{C}_{2}\right)$ are changing mutually, the weights of the organization $\left(\mathrm{C}_{3}\right)$, transportation and distribution $\left(\mathrm{C}_{4}\right)$, and management and planning $\left(\mathrm{C}_{5}\right)$ are constant as presented in Table 11 for Scenario 1. For this reason, the weights gained from TIT2FAHP are changed for two main criteria while the others are constant. 
Table 11. The weights of main criteria for sensitivity analysis of scenarios

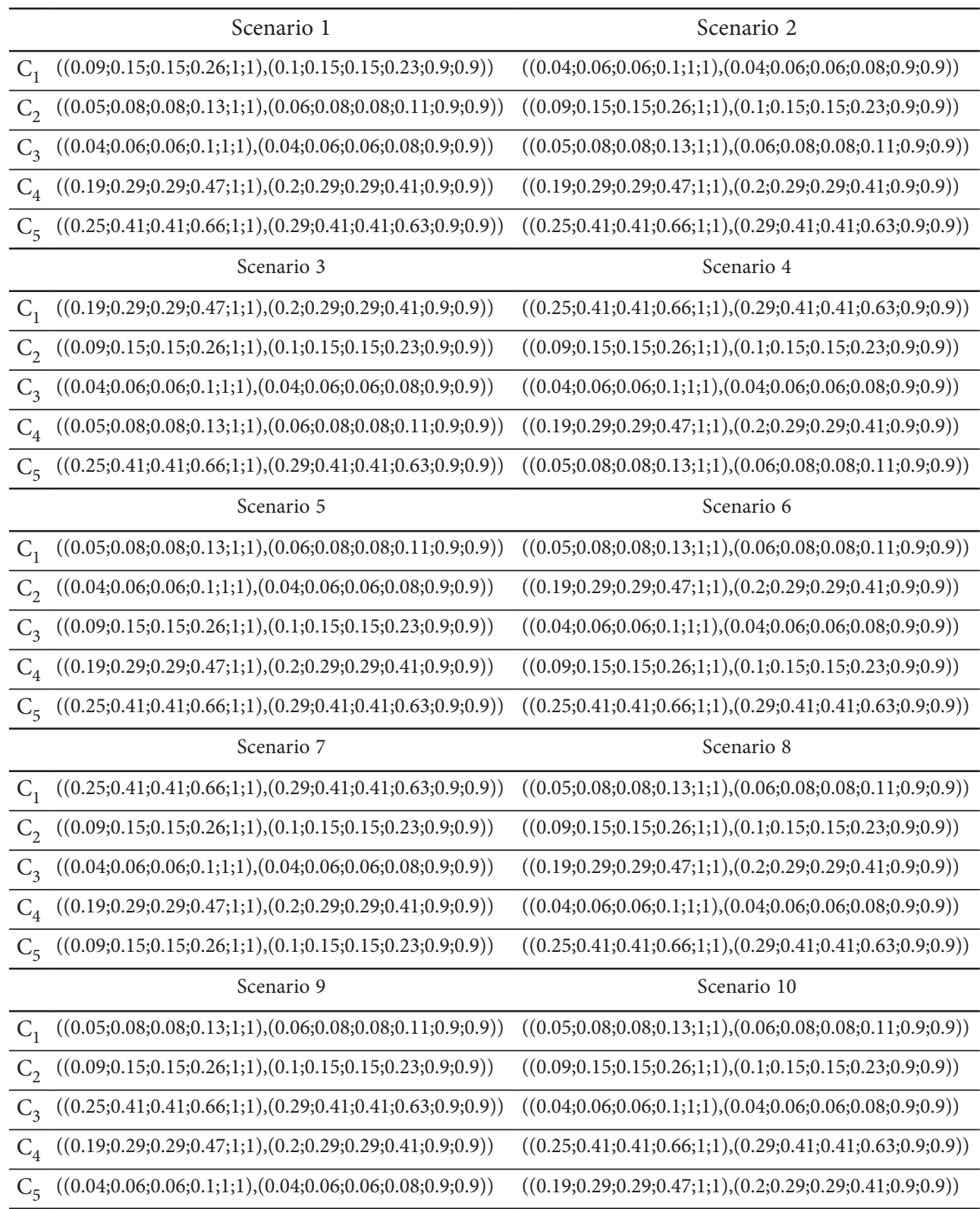

The results of the sensitivity analysis can be seen from Table 12 and graphically from Figure 4. According to the sensitivity analysis results, the value of closeness coefficient is changing but the ranking of the NGOs is same. As it is clearly seen, $\mathrm{NGO}_{3}$ is always the best and $\mathrm{NGO}_{4}$ is the worst alternative whatever the weights for criteria is changed (From scenario 1 to 10 ). 
Table 12 . The sensitivity analysis results

\begin{tabular}{cccccc}
\hline & Scenario 1 & Scenario 2 & Scenario 3 & Scenario 4 & Scenario 5 \\
\hline $\mathrm{NGO}_{1}$ & 0.0276 & 0.0275 & 0.0279 & 0.0278 & 0.0274 \\
\hline $\mathrm{NGO}_{2}$ & 0.0282 & 0.0284 & 0.0286 & 0.0285 & 0.0283 \\
\hline $\mathrm{NGO}_{3}$ & 0.0327 & 0.0326 & 0.0324 & 0.0322 & 0.0325 \\
\hline $\mathrm{NGO}_{4}$ & 0.0226 & 0.0230 & 0.0233 & 0.0222 & 0.0228 \\
\hline & Scenario 6 & Scenario 7 & Scenario 8 & Scenario 9 & Scenario 10 \\
\hline $\mathrm{NGO}_{1}$ & 0.0277 & 0.0277 & 0.0275 & 0.0272 & 0.0274 \\
\hline $\mathrm{NGO}_{2}$ & 0.0287 & 0.0289 & 0.0289 & 0.0289 & 0.0283 \\
\hline $\mathrm{NGO}_{3}$ & 0.0325 & 0.0323 & 0.0319 & 0.0314 & 0.0326 \\
\hline $\mathrm{NGO}_{4}$ & 0.0237 & 0.0235 & 0.0241 & 0.0234 & 0.0224 \\
\hline
\end{tabular}

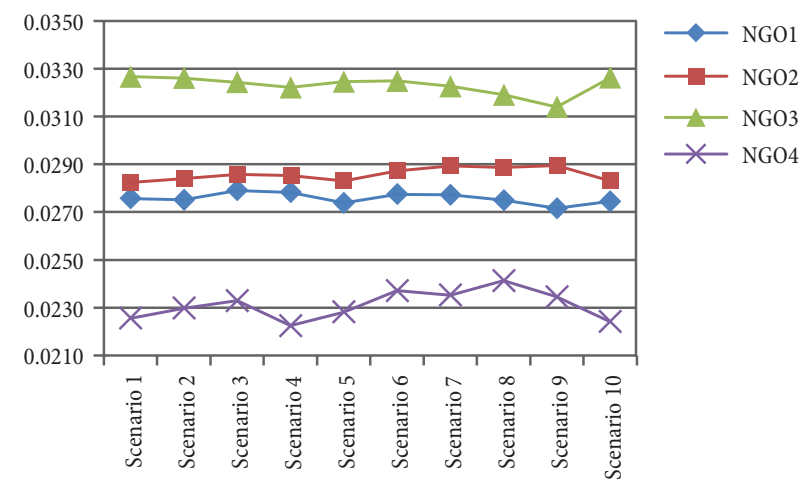

Fig. 4. Model result changes caused by the sensitivity analysis

\section{Conclusions}

All humanitarian relief actors must develop their performances for preparedness and response ability to a disaster because there is a lack of resources. NGOs are also accountable and have reporting responsibilities to their shareholders. On the other hand, if NGOs fail to focus on their performances for preparedness and response abilities, it may result in dissatisfaction and it jeopardizes immediate and future funding of the NGOs and other aspects of the relief effort. Therefore, it is crucial for NGOs to find a suitable approach to evaluate their preparedness and response abilities. In this paper, a hybrid AHP and TOPSIS method based on trapezoidal interval type-2 fuzzy sets is proposed to evaluate the performance of preparedness and response ability of NGOs. This hybrid fuzzy method has the ability to capture the vagueness of human thinking style and effectively solve multi-criteria decision making problems due to the fact that it uses interval type- 2 fuzzy sets rather than type- 1 fuzzy sets to represent the evaluating values and the weights of attributes.

The contributions of the paper to the literature are as follows: (1) By conducting a literature review and surveys with the expert interviewees, the criteria and sub-criteria representing CSFs are determined and categorized for NGOs; (2) it presents a novel per- 
formance evaluation model for NGOs for their HRLM operations by TIT2AHP and TIT2TOPSIS integration. By using these two methods together and in an integrated way, the CSF evaluations can be made in a more healthy manner; (3) this hybrid fuzzy method has the ability to capture the vagueness of human thinking style and effectively solve multicriteria decision making problems due to the fact that it uses interval type- 2 fuzzy sets, rather than type-1 fuzzy sets to represent the evaluating values and the weights of attributes; (4) the proposed method can be applied to any complex decision making problem which encounters imprecise, indefinite, and subjective data or vague information, i.e. manufacturing, organizational management, information systems, social sciences, etc.; as proved by sensitivity analysis considering expert importance weights changing; (5) it is aimed that, the proposed method will be used in different and possible disaster areas in our country, and in non-governmental organizations to evaluate their humanitarian relief operation performance.

The critical success factor can be investigated in detail based on literature review and the experts' decision. The proposed hybrid method can be applied to different numbers of NGOs and the NGOs of other countries. It can be also applied to manufacturing, organization management, information system and social science decision making problems. Besides, it is applicable to all systems facing problems that require hierarchical decision making.

\section{Acknowledgements}

We would like to thank experts from Deniz Feneri Association, Kimse Yok Mu Association, The Foundation for Human Rights and Freedoms and Humanitarian Relief, and Yardımeli Association and AFAD for their helpful comments. In carrying out this research, the authors have been supported by the Yildiz Technical University Scientific Research Project Fund with Grant No: 2013-06-03-KAP01. This fund is hereby gratefully acknowledged. Finally, the authors would like to thank the anonymous referees for their helpful comments and suggested improvements.

\section{References}

Abidi, H.; de Leeuw, S.; Klumpp, M. 2013. Measuring success in humanitarian supply chains, International Journal of Business and Management Invention 2: 31-39.

Abidi, H.; de Leeuw, S.; Klumpp, M. 2014. Humanitarian supply chain performance management: a systematic literature review, Supply Chain Management: An International Journal 19: 592-608. http://dx.doi.org/10.1108/SCM-09-2013-0349

Aiello, G.; Enea, M.; Galante, G.; La Scalia, G. 2009. Clean agent selection approached by fuzzy TOPSIS decision-making method, Fire Technology 45: 405-418. http://dx.doi.org/10.1007/s10694-008-0059-3

Apte, A. 2009. Humanitarian logistics: a new field of research and action, foundations and trends in technology, Information and Operations Management 3(1): 1-100. http://dx.doi.org/10.1561/0200000014

Balcik, B.; Beamon, B. M.; Krejci, C. C.; Muramatsu, K. M.; Ramirez, M. 2010. Coordination in humanitarian relief chains: practices, challenges and opportunities, International Journal of Production Economics 126(1): 22-34. http://dx.doi.org/10.1016/j.ijpe.2009.09.008 
Balcik, B.; Beamon, B. M. 2008. Facility location in humanitarian relief, International Journal of Logistics Research and Applications: A Leading Journal of Supply Chain Management 11(2): 101-121. http://dx.doi.org/10.1080/13675560701561789

Beamon, B. M.; Balcik, B. 2008. Performance measurement in humanitarian relief chains, International Journal of Public Sector Management 21(1): 4-25. http://dx.doi.org/10.1108/09513550810846087

Beamon, B. M.; Kotleba, S. A. 2006. Inventory management support systems for emergency humanitarian relief operations in South Sudan, The International Journal of Logistics Management 17(2): 187-212. http://dx.doi.org/10.1108/09574090610689952

Behzadian, M.; Khanmohammadi Otaghsara, S.; Yazdani, M.; Ignatius, J. 2012. A state-of the-art survey of TOPSIS applications, Expert Systems with Applications 39(17): 13051-13069. http://dx.doi.org/10.1016/j.eswa.2012.05.056

Buckley, J. J. 1985. Fuzzy hierarchical analysis, Fuzzy Sets and Systems 17: 233-247. http://dx.doi.org/10.1016/0165-0114(85)90090-9

Bui, T.; Cho, S.; Sankaran, S.; Sovereign, M. 2000. A framework for designing a global information network for multinational humanitarian assistance/disaster relief, Information Systems Frontiers 1(4): 427-442. http://dx.doi.org/10.1023/A:1010074210709

Buyukozkan, G.; Feyzioglu, O.; Nebol, E. 2008. Selection of the strategic alliance partner in logistics value chain, International Journal of Production Economics 113: 148-158.

http://dx.doi.org/10.1016/j.ijpe.2007.01.016

Celik, E.; Bilisik, O. N.; Erdogan, M.; Gumus, A. T.; Baracli, H. 2013b. An integrated novel interval type-2 fuzzy MCDM method to improve customer satisfaction in public transportation for Istanbul, Transportation Research Part E: Logistics and Transportation Review 58: 28-51. http://dx.doi.org/10.1016/j.tre.2013.06.006

Celik, E.; Gul, M.; Gumus, A. T.; Guneri, A. F. 2012. A fuzzy TOPSIS approach based on trapezoidal numbers to material selection problem, Journal of Information Technology Applications \& Management 19(3): 19-30.

Celik, E.; Gumus, A. T.; Alegoz, A. 2013a. A trapezoidal type-2 fuzzy MCDM method to identify and evaluate critical success factors for humanitarian relief logistics management, in Proc. of the 3rd International Fuzzy Systems Symposium (FUZZYSS'13), 24-25 October 2013, Istanbul, Turkey, 168-173.

Chen, C. T. 2000. Extensions of the TOPSIS for group decision-making under fuzzy environment, Fuzzy Sets and Systems 114(1): 1-9. http://dx.doi.org/10.1016/S0165-0114(97)00377-1

Chen, S. J.; Hwang, C. L. 1992. Fuzzy multiple attribute decision making: methods and applications. Berlin: Springer-Verlag. http://dx.doi.org/10.1007/978-3-642-46768-4

Chen, S. M.; Lee, L. W. 2010. Fuzzy multiple attributes group decision-making based on the interval type-2 TOPSIS method, Expert Systems with Applications 37(4): 2790-2798. http://dx.doi.org/10.1016/j.eswa.2009.09.012

Chia, E. S. 2007. Engineering disaster relief, IEEE Technology and Society Magazine 2007 (Fall): 24-29. http://dx.doi.org/10.1109/MTS.2007.906673

Daniel, D. R. 1961. Management information crisis, Harvard Business Review 39(5): 111-121.

Davidson, A. L. 2006. Key performance indicators in humanitarian logistics: Master Thesis of Engineering in Logistics. Massachusetts Institute of Technology, Cambridge, MA.

Disparte, D. 2007. The postman's parallel, Car Nation 2: 22-27.

Döyen, A.; Aras, N.; Barbarosoğlu, G. 2012. A two-echelon stochastic facility location model for humanitarian relief logistics, Optimization Letters 6(6): 1123-1145.

http://dx.doi.org/10.1007/s11590-011-0421-0 
Duran, S.; Gutierrez, M. A.; Keskinocak, P. 2011. Pre-positioning of emergency items for CARE international, Interfaces 41(3): 223-237. http://dx.doi.org/10.1287/inte.1100.0526

EM-DAT. 2013. EM-DAT - Emergency Events Database. Centre for Research on the Epidemiology of Disasters (CRED), Universite' Catholique de Louvain, Louvain-La-Neuve [online], [cited 15 May 2013]. Available from internet: www.emdat.be

Ertugrul, I.; Karakasoglu, N. 2008. Comparison of fuzzy AHP and fuzzy TOPSIS methods for facility location selection, International Journal of Advanced Manufacturing Technology 39: 783-795. http://dx.doi.org/10.1007/s00170-007-1249-8

Freund, Y. P. 1988. Critical success factors, Strategy \& Leadership 16(4): 20-23. http://dx.doi.org/10.1108/eb054225

Fritz Institute. 2005. Logistics and the effective delivery of humanitarian relief. Fritz Institute, San Francisco, CA. 12 p.

Garcia-Cascales, M. S.; Lamata, M. T. 2009. Multi-criteria analysis for a maintenance management problem in an engine factory: rational choice, Journal of Intelligent Manufacturing 22(5): 779-788. http://dx.doi.org/10.1007/s10845-009-0290-x

Gumus, A. T. 2009. Evaluation of hazardous waste transportation firms by using a two step fuzzy-AHP and TOPSIS methodology, Expert Systems with Applications 36(2): 4067-4074. http://dx.doi.org/10.1016/j.eswa.2008.03.013

Gumus, A. T.; Yayla, A. Y.; Çelik, E.; Yildiz, A. 2013. A combined Fuzzy-AHP and Fuzzy-GRA methodology for hydrogen energy storage method selection in Turkey, Energies 6(6): 3017-3032. http://dx.doi.org/10.3390/en6063017

Gunasekaran, A.; Ngai, E. W. T. 2003. The successful management of a small logistics company, International Journal of Physical Distribution \& Logistics Management 33(9): 825-842. http://dx.doi.org/10.1108/09600030310503352

Gunnec, D.; Salman, F. S. 2007. A two-stage multi-criteria stochastic programming model for location of emergency response and distribution centers, in Proc. of the International Network Optimization Conference (INOC), 22-25 April 2007, Spa, Belgium.

Holland, C. R.; Light, B. 1999. A critical success factors model for ERP implementation, IEEE Software 16(3): 30-36. http://doi.ieeecomputersociety.org/10.1109/52.765784

Hwang, C. L.; Yoon, K. 1981. Multiple attribute decision making-methods and applications. Heidelberg: Springer-Verlag. http://dx.doi.org/10.1007/978-3-642-48318-9

Jia, H.; Ordóñez, F.; Dessouky, M. 2007. A modeling framework for facility location of medical services for large-scale emergencies, IIE Transactions 39(1): 41-55. http://dx.doi.org/10.1080/07408170500539113

Jolai, F.; Yazdian, S. A.; Shahanaghi, K.; Azari-Khojasteh, M. 2011. Integrating fuzzy TOPSIS and multiperiod goal programming for purchasing multiple products from multiple suppliers, Journal of Purchasing \& Supply Management 17: 42-53. http://dx.doi.org/10.1016/j.pursup.2010.06.004

Ju, Y.; Wang, A.; Liu, X. 2012. Evaluating emergency response capacity by fuzzy AHP and 2-tuple fuzzy linguistic approach, Expert Systems with Applications 39(8): 6972-6981. http://dx.doi.org/10.1016/j.eswa.2012.01.061

Kahraman, C.; Suder, A.; Cebi, S. 2013. Fuzzy multi-criteria and multi-experts evaluation of government investments in higher education: the case of Turkey, Technological and Economic Development of Economy 19(4): 549-569. http://dx.doi.org/10.3846/20294913.2013.837110

Kovacs, G.; Spens, K. M. 2007. Humanitarian logistics in disaster relief operations, International Journal of Physical Distribution and Logistics Management 37: 99-114.

http://dx.doi.org/10.1108/09600030710734820 
Lee, L. W.; Chen, S. M. 2008. Fuzzy multiple attributes group decision-making based on the extension of TOPSIS method and interval type-2 fuzzy sets, in Proc. of the $7^{\text {th }}$ International Conference on Machine Learning and Cybernetic, 12-15 July 2008, Kumming, China, 3260-3265.

Leiras, A.; de Brito Jr, I.; Peres, E. Q.; Bertazzo, T. R.; Yoshizaki, H. T. Y. 2014. Literature review of humanitarian logistics research: trends and challenges, Journal of Humanitarian Logistics and Supply Chain Management 4(1): 95-130. http://dx.doi.org/10.1108/JHLSCM-04-2012-0008

Li, T.; Jin, J.; Li, C. 2012. Refractured well selection for multicriteria group decision making by integrating fuzzy AHP with fuzzy TOPSIS based on interval-typed fuzzy numbers, Journal of Applied Mathematics, 1-21. http://dx.doi.org/10.1155/2012/304287

Lu, D. K.; Pettit, S.; Beresford, A. 2006. Critical success factors for emergency relief logistics, Whampoa: An Interdisciplinary Journal 51(1): 177-184.

Mardani, A.; Jusoh, A.; Zavadskas, E. K. 2015. Fuzzy multiple criteria decision-making techniques and applications - two decades review from 1994 to 2014, Expert Systems with Applications 42(8): 4126-4148. http://dx.doi.org/10.1016/j.eswa.2015.01.003

Marx, M. 2009. Coordinating international response to humanitarian crises, in Proceedings of Humanitarian Logistics Conference, 19-20 February 2009, Georgia, Atlanta. H. Milton Stewart School of Industrial and Systems Engineering at Georgia Tech, Atlanta, USA.

Mendel, J. M.; John, R. I.; Liu, F. 2006. Interval type-2 fuzzy logic systems made simple, Fuzzy Systems, IEEE Transactions on 14(6): 808-821. http://dx.doi.org/10.1109/TFUZZ.2006.879986

Moe, T. L.; Gehbauer, F.; Senitz, S.; Mueller, M. 2007. Balanced scorecard for natural disaster management projects, Disaster Prevention and Management: An International Journal 16(5): 785-806. http://dx.doi.org/10.1108/09653560710837073

Moe, T. L.; Pathranarakul, P. 2006. An integrated approach to natural disaster management: public project management and its critical success factors, Disaster Prevention and Management: An International Journal 15(3): 396-413. http://dx.doi.org/10.1108/09653560610669882

Nasab, F. G.; Rostamy-Malkhalifeh, M. 2010. Extension of TOPSIS for group decision-making based on the type-2 fuzzy positive and negative ideal solutions, International Journal of Industrial Mathematics 2(3): 199-213.

Natarajarathinam, M.; Capar, I.; Narayanan, A. 2009. Managing supply chains in times of crisis: a review of literature and insights, International Journal of Physical Distribution \& Logistics Management 39(7): 535-573. http://dx.doi.org/10.1108/09600030910996251

Oloruntoba, R. 2005. A wave of destruction and the waves of relief: issues, challenges and strategies, Disaster Prevention and Management: An International Journal 4: 506-521. http://dx.doi.org/10.1108/09653560510618348

Oloruntoba, R. 2010. An analysis of the Cyclone Larry emergency relief chain: some key success factors, International Journal of Production Economics 126: 85-101. http://dx.doi.org/10.1016/j.ijpe.2009.10.013

Onut, S.; Soner, S. 2008. Transshipment site selection using the AHP and TOPSIS approaches under fuzzy environment, Waste Management 28: 1552-1559. http://dx.doi.org/10.1016/j.wasman.2007.05.019

Pettit, S.; Beresford, A. 2009. Critical success factors in the context of humanitarian aid supply chains, International Journal of Physical Distribution \& Logistics Management 39(6): 450-468. http://dx.doi.org/10.1108/09600030910985811

Pettit, S. J.; Beresford, A. K. C. 2005. Emergency relief logistics: an evaluation of military, non-military and composite response models, International Journal of Logistics Research and Applications: A Leading Journal of Supply Chain Management 8(4): 313-331. http://dx.doi.org/10.1080/13675560500407325

Power, D.; Amrik, J.; Sohal, S.; Rahman, S. U. 2001. Critical success factors in agile supply chain management - an empirical study, International Journal of Physical Distribution \& Logistics Management 31(4): 247-265. http://dx.doi.org/10.1108/09600030110394923 
Rathod, M. K.; Kanzaria, H. V. 2011. A methodological concept for phase change material selection based on multiple criteria decision analysis with and without fuzzy environment, Materials and Design 32: 3578-3585. http://dx.doi.org/10.1016/j.matdes.2011.02.040

Rawls, C. G.; Turnquist, M. A. 2010. Pre-positioning of emergency supplies for disaster response, Transportation Research Part B: Methodological 44(4): 521-534. http://dx.doi.org/10.1016/j.trb.2009.08.003

Rostamzadeh, R.; Sofian, S. 2011. Prioritizing effective 7Ms to improve production systems performance using fuzzy AHP and fuzzy TOPSIS (case study), Expert Systems with Applications 38: 5166-5177. http://dx.doi.org/10.1016/j.eswa.2010.10.045

Saaty, T. L. 1980. The analytic hierarchy process. New York: McGraw-Hill.

Sandwell, C. 2011. A qualitative study exploring the challenges of humanitarian organisations, Journal of Humanitarian Logistics and Supply Chain Management 1(2): 132-150.

http://dx.doi.org/10.1108/20426741111158430

Seneviratne, K.; Baldry, D.; Pathirage, C. 2010. Disaster knowledge factors in managing disasters successfully, International Journal of Strategic Property Management 14(4): 376-390 http://dx.doi.org/10.3846/ijspm.2010.28

Sumner, M. 1999. Critical success factors in enterprise wide information management systems projects, in Proc. of the 1999 ACM SIGCPR Conference on Computer Personnel Research, 1999, New York, USA, 297-303.

Sun, C. C. 2010. A performance evaluation model by integrating fuzzy AHP and fuzzy TOPSIS methods, Expert Systems with Applications 37: 7745-7754. http://dx.doi.org/10.1016/j.eswa.2010.04.066

Tomasini, R. M.; Van Wassenhove, L. N. 2009. Humanitarian logistics. New York: INSEAD Business Press. http://dx.doi.org/10.1057/9780230233485

Tsaur, S. H.; Chang, T. Y.; Yen, C. H. 2002. The evaluation of airline service quality by fuzzy MCDM, Tourism Management 23: 107-115. http://dx.doi.org/10.1016/S0261-5177(01)00050-4

Van Wassenhove, L. N.; Pedraza Martinez, A. J. 2012. Using OR to adapt supply chain management best practices to humanitarian logistics, International Transactions in Operational Research 19(1-2): 307-322. http://dx.doi.org/10.1111/j.1475-3995.2010.00792.x

Wang, J. W.; Cheng, C. H.; Huang, K. C. 2009. Fuzzy hierarchical TOPSIS for supplier selection, Applied Soft Computing 9: 377-386. http://dx.doi.org/10.1016/j.asoc.2008.04.014

Whybark, D. C. 2007. Issues in managing disaster relief inventories, International Journal of Production Economics 108(1): 228-235. http://dx.doi.org/10.1016/j.ijpe.2006.12.012

Yoon, K. P.; Hwang, C. L. 1995. Multiple attribute decision making. Thousand Oaks, CA: Sage Publication.

Yushimito, W. F.; Jaller, M.; Ukkusuri, S. 2012. A Voronoi-based heuristic algorithm for locating distribution centers in disasters, Networks and Spatial Economics 12(1): 21-39. http://dx.doi.org/10.1007/s11067-010-9140-9

Zavadskas, E. K.; Turskis, Z.; Kildienè, S. 2014. State of art surveys of overviews on MCDM/MADM methods, Technological and Economic Development of Economy 20(1): 165-179. http://dx.doi.org/10.3846/20294913.2014.892037

Zeydan, M.; Çolpan, C.; Çobanoglu, C. 2011. A combined methodology for supplier selection and performance evaluation, Expert Systems with Applications 38: 2741-2751.

http://dx.doi.org/10.1016/j.eswa.2010.08.064

Zhou, Q.; Weilai, H.; Ying, Z. 2011. Identifying critical success factors in emergency management using a fuzzy DEMATEL method, Safety Science 49(2): 243-252.

http://dx.doi.org/10.1016/j.ssci.2010.08.005 
Erkan CELIK. He is a Research Assistant in the Department of Industrial Engineering at Yildiz Technical University, Istanbul, Turkey and Department of Industrial Engineering at Tunceli University, Tunceli, Turkey. He received BSc and MSc degree in Industrial Engineering from Selcuk University, Konya, Turkey in 2008 and 2011, respectively. His research interests are in decision analysis, humanitarian logistic, fuzzy sets.

Alev TASKIN GUMUS. She is an Associate Professor in Department of Industrial Engineering, Yildiz Technical University, Istanbul, Turkey. She received BSc and MSc in Industrial Engineering from Yildiz Technical University, MBA from Istanbul Technical University and $\mathrm{PhD}$ in Industrial Engineering from Yildiz Technical University. She completed post-doctoral research at Zaragoza Logistics Center, Spain. Her research interests are in supply chain management, production and inventory systems, decision analysis, artificial intelligence and fuzzy logic applications in industrial engineering and management sciences. 